\title{
Cretaceous to Mid-Eocene pelagic sediment budget in Puerto Rico and the Virgin Islands (northeast Antilles Island arc)
}

\author{
W.T. JOLLY 11 E.G. LIDIAK ${ }^{2} \mid$ and A.P. DICKIN ${ }^{3} \mid$ \\ | 1 | Department of Earth Sciences, Brock University \\ St. Catharines, Ontario, Canada L2S 3A1. E-mail: wayne@craton.geol.brocku.ca \\ | 2 | Department of Geology and Planetary Science, University of Pittsburgh \\ Pittsburgh, PA, USA 15260. E-mail: eg|+@pitt.edu \\ 3 | Department of Geology and Geography, McMaster University \\ Hamilton, Ontario, Canada L8S 4M1. E-Mail: dickin@mcmaster.ca
}

\begin{abstract}
Island arc basalts (IAB) in the Greater Antilles, dating between Albian and mid-Eocene time ( 112 to $45 \mathrm{Ma}$ ), consist of an early low-K, primitive island arc (PIA) basalt series and a later, predominantly intermediate calcalkaline (CA) series. The rocks resemble modern sediment-poor, low-light rare earth element (LREE)/heavy rare earth element (HREE) arc basalts from intra-oceanic tectonic settings and sediment-rich, high-LREE/HREE types from continental margin arcs, respectively. Isotope and incompatible trace element distribution along a $450 \mathrm{~km}$ segment of the arc in the northeast Antilles demonstrates that low-LREE/HREE basalts predominate in Albian to Santonian ( 85 Ma) stratigraphic sequences in the Virgin Islands (VI) and northeast Puerto Rico (NEPR), while there is a gradual but spectacular increase in both LREE/HREE and absolute abundances of incompatible elements in central Puerto Rico (CPR). Northeastern Antilles basalts have consistently elevated $\mathrm{La} / \mathrm{Nb}$ and relatively low $\mathrm{Nb} / \mathrm{Zr}$, both inconsistent with the presence of a significant ocean island basalt component. Hence, observed differences are interpreted to reflect variation in proportions of pelagic sediment subducted by the south-dipping Antilles arc system as it swept north-eastward across the Caribbean region and eventually approached the Bahama Banks along the south-eastern fringes of the North American Plate. Trace element mixing models indicate sediment proportions in VI and NEPR were limited, averaging considerably below $1.0 \%$. In comparison sediment content in CPR increased from an average slightly above $1.0 \%$ in Albian ( 112 Ma) basalts to as high as $8 \%$ in Cenomanian (100-94 Ma) types. Hypothetical pre-arc pelagic sedimentary facies in the subducted proto-Atlantic (or proto-Caribbean) basin, included 1) a young, centrally located longitudinal ridge-crest facies, with a thin sediment cover, eventually subducted by VI and NEPR, 2) a slightly older basin-margin facies of variable width and moderate sediment thickness, subducted by CPR during Albian time, and 3) a thick, pre-arc continental margin facies in the vicinity of Central America, subducted by CPR during Cenomanian time. Following collision of neighboring Hispaniola with the Bahamas sediment budgets in the northeast Antilles stabilized at moderate levels from 2 to $3 \%$, reflecting widespread subduction of North Atlantic Cretaceous pelagic sediment (AKPS).
\end{abstract}

\begin{tabular}{l|l} 
KEYWORDS & Island arc. Antilles. Cretaceous. Pelagic sediment. Mantle melting.
\end{tabular} 


\section{INTRODUCTION}

Early Cretaceous to mid-Eocene island arc basalts (IAB) in the Greater Antilles (Fig. 1) are traditionally subdivided (Donnelly et al., 1990; Lebron and Perfit, 1994) into a lower primitive island arc suite (PIA), consisting predominantly of quartz-bearing dacitic lava and lava breccia (keratophyre) accompanied by degraded low$\mathrm{K}$ basalt (spilite), and an overlying basaltic to intermediate calc-alkaline suite (CA). Plagioclase and augite dominate phenocryst assemblages in both suites, while pseudomorphs of olivine and amphibole are rare or absent, even in felsic end-members, until Tertiary time. PIA lavas typically have low large-ion lithophile (LILE), rare earth (REE), and high field strength element (HFSE) abundances, low $\mathrm{Th}, \mathrm{U}$, and radiogenic $\mathrm{Pb}$, and near-horizontal normalized REE spectra. Original definitions of PIA (Donnelly and Rogers, 1980) stipulated marked bimodality with respect to $\mathrm{SiO}_{2}$, as exemplified by the Water Island Formation in the Virgin Islands (Hekinian, 1971) and Los Ranchos Formation in Hispaniola (Kesler and Campbell, 2005). However, subsequent investigations (Schellekens, 1998; Jolly et al., 1998a) revealed true bimodality is absent from early Puerto Rican IAB, and is absent or subdued in Hispaniola (Lewis et al., 2002). Younger CA lavas in the northeast Antilles are distinguished from PIA by elevated incompatible element abundances and variably enriched REE patterns. Trace element abundances in modern island arcs are closely linked to compositions and proportions of subducted pelagic sediment (Hawkesworth and Powell, 1980; Arculus and Powell, 1986). Accordingly, Hawkesworth et al. (1993) subdivided arc basalts $\left(\mathrm{SiO}_{2}<55 \%\right.$, Fig. 2A) into 1) a low-LREE/HREE series, comprising intra-oceanic arc suites with low (New Britain, Woodhead et al., 1998; South Sandwich, Cohen and O’Nions, 1982; Tonga,
Ewart and Hawkesworth, 1987) to moderate (Aleutians, Romik et al., 1990; Japan, Tatsumi et al., 1988; Northern Lesser Antilles, Davidson, 1986, 1987) sediment proportions, and 2) a high-LREE/HREE series, comprising continental margin arc suites with elevated pelagic sediment proportions (Aeolian Is., Ellam et al., 1988; Grenada, Thirlwall and Graham, 1984; Philippines, McDermott et al., 1993).

Northeast Antilles PIA and CA basalts are broadly equivalent to modern low- and high-LREE/HREE types, respectively (Fig. 2B). Hence, Antillian island arc volcanism produced basalt compositions that extend across the entire modern LREE/HREE spectrum, reflecting wide variation in proportions of pelagic sediment subducted by the arc during its 80 million year long eruptive history (Schellekens, 1998). The principal objectives of this paper include both 1) examination of geographic and temporal compositional variability along a $450 \mathrm{~km}$ section of the northeast Antilles arc system from the Anegada Fault Zone to Mona Passage (Fig. 2), and 2) assessment of tectonic implications of observed disparities. For these purposes chronological trends in pelagic sediment budgets key incompatible trace element parameters are ascertained for three discrete regions (Fig. 3), including Central Puerto Rico in the west, north-eastern Puerto Rico in the central zone, and the Virgin Islands in the east. Additional Santonian to mid-Eocene island arc strata are present in southwestern Puerto Rico. These rocks are not included in this investigation because they have distinctive incompatible element-rich compositions (Schellekens, 1998), and form northwest-trending belts that truncate dominantly east-west trends in eastern Puerto Rico. The southwestern strata, therefore, are considered to represent arc deposits developed in association with an independent subduction zone.

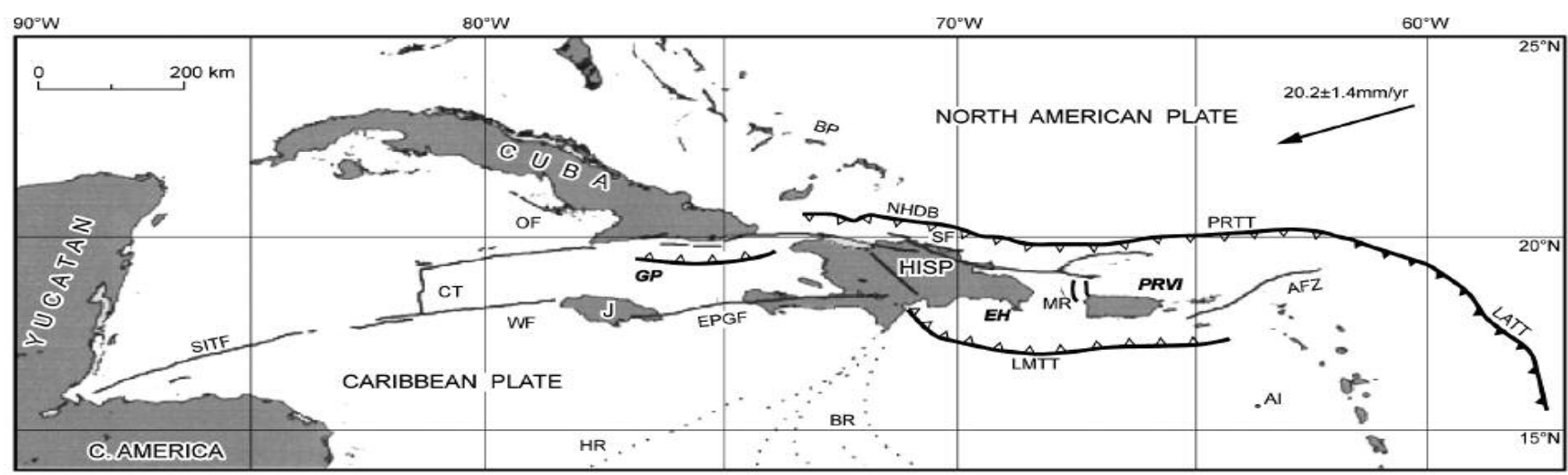

FIGURE 1 Map of the northern Caribbean plate boundary showing microplates (bold) and tectonic features (modified from Jansma et al., 2000). AFZ: Anegada fault zone; Al: Aves Island; BP: Bahamas Platform; BR: Beata Ridge; CT: Cayman Trough Spreading Center; EH: Hispaniola microplate; EPGF: Enriquillo-Plantain Garden Fault; GP: Gonaive microplate; HISP: Hispaniola; HR: Hess Rise; J: Jamaica; LATMT: Lesser Antilles Trench Thrust; MR: Mona Rift; LMTT: Los Muertos Trench Thrust; NHDB: north Hispaniola deformed belt; OF: Orients Fault; PRTMT: Puerto Rico Trench Thrust; PRVI: Puerto Rico-Virgin Islands microplate; SITF: Swan Is. Transform Fault; SF: Septentrional Fault; WF: Walton Fault. North American vector (relative to a static Caribbean) is from Jansma et al. (2000). 


\section{GEOLOGICAL SETTING}

\section{General relations}

The Antilles Island Arc is subdivided naturally into two segments: 1) the extinct Late Mesozoic to Paleogene Greater Antilles in the north, including Cuba, Jamaica, Hispaniola, Puerto Rico, and the Virgin Islands, and 2) the volcanically active Lesser Antilles in the southeast (Fig. 1), which rest on buried remnants of the south-eastern extension of the Mesozoic arc. The ancient Greater Antilles island arc platform is geologically significant because it preserves a continuous record of subduction along the boundary between the North American and Caribbean Plates from Aptian-Albian in the Early Cretaceous to mid-Eocene time (approximately 125 to $45 \mathrm{Ma}$; Pindell and Barrett, 1990; Schellekens, 1998; Jolly et al., 1998a and b; Iturralde-Vinent and McPhee, 1995; Lewis et al., 2002), a total of over $80 \mathrm{my}$. Of principal interest here is the northeastern sector, the Puerto Rico - Virgin Islands microplate (PRVI) of Jansma et al. (2000), which occupies the broad zone between the diffuse Puerto Rico Trench Thrust on the north and the Los Muertos Trench Thrust on the south, and extends almost $450 \mathrm{~km}$ eastward from Mona Passage to the Anegada Fault Zone (Fig. 3).

Exposures of basement rocks are absent in most islands of the northeast Antilles east of Hispaniola, but a Jurassic sequence of MORB tholeiites (Schellekens et al., 1990), accompanied by serpentinized peridotite (Sierra Bermeja Complex of Mattson, 1960; Fig. 3) and pelagic radiolarian chert (Mariquita Chert) of Pacific (Farallon) origin (Montgomery et al., 1994), is thought to represent pre-arc oceanic basement in western Puerto Rico (Schellekens et al., 1990). Because oldest exposed arc strata date approximately from early Cretaceous time in all the islands, and because geochemical and lithological sequences are similar, the modern Antilles arc platform is considered to be remnants of a once continuous volcanic arc chain that formed in the eastern Pacific and was subsequently inserted eastward into the modern Caribbean region along the eastern flank of the Pacific Plate (Mattson, 1979; Burke, 1988; Donnelly, 1989; Pindell and Barrett, 1990; Draper et al., 1996; Schellekens, 1998; Lewis et al., 2002).

\section{Virgin Islands}

The oldest unit in the Virgin Islands (Fig. 4), dated by radiolarians to between latest Aptian and earliest Albian time (Rankin, 2002), is the aphanitic to coarse-grained, plagioclase-augite-bearing Water Island Formation (Fig. 5). Dacitic ( $80 \%)$ and basaltic $(20 \%)$ lava and lava breccia accompanied by pelagic chert normally predominate in this 2 to $4 \mathrm{~km}$ thick bimodal unit, but on St. John (Fig. 4) the Water Island Fm includes high angle sheeted basaltic dike swarms (Rankin, 2002; Jolly and Lidiak, this vol-

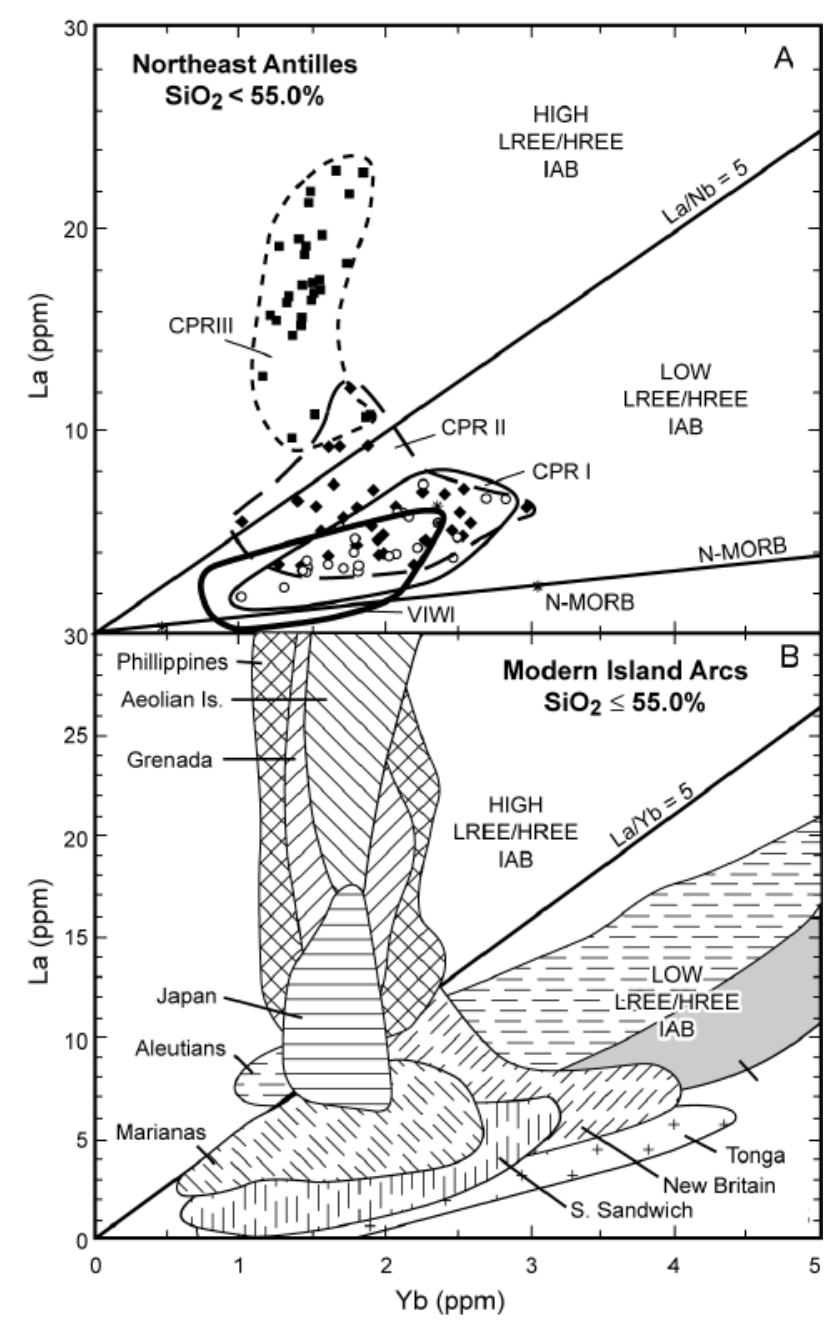

FIGURE 2 A) Covariation of $\mathrm{La}$ and $\mathrm{Yb}$ in basalts ( $\mathrm{SiO}_{2}<55 \%$ ) from central Puerto Rico (CPR) and the Water Island Fm, Virgin Islands (VIWI); symbols as indicated. B) Covariation of La and $\mathrm{Yb}$ in intraoceanic and continental margin island arc basalts (see text for references).

ume). Discordance between these features, initially identified as bedding, and overlying strata of the Louisenhoj Fm was originally regarded as evidence of angular unconformity (Donnelly, 1966). On the contrary, field relations demonstrate that the Water Island Fm grades conformably upward into volcanic conglomerate, sand, and tuffaceous shale of the overlying Louisenhoj Fm (Rankin, 2002). The Louisenhoj, a 0.5 to $1.5 \mathrm{~km}$ thick, PIA-type basaltic unit, is in turn overlain conformably by a relatively thin, but highly significant carbonate unit, the Outer Brass Limestone. This unit, dated conclusively by abundant planktonic Foraminifera to between Late Turonian and Late Santonian time, effectively constrains ages of the upper Louisenhoj Fm and lower parts of the succeeding, also conformable, Tutu Fm (Rankin, 2002).

Tutu calcalkaline volcaniclastic strata are restricted to a narrow belt in the core of the east-west oriented 
Narrows Syncline (Fig. 4), with subparallel north-dipping Water Island - Louisenhoj strata on the south flank. Donnelly (1960) and Helsley (1960) originally mapped the unfossiliferous, south-dipping strata on Hans Lollok Island as overturned, and considered the rocks to represent a western extension of the Eocene Tortola Fm, whereas Rankin (2002) considered Hans Lollik strata immediately north of the syncline as being upright, and inferred the rocks pre-dated the Campanian Tutu Fm. Consequently, the Tortola Fm is restricted here to units exposed in the British Virgin Islands, and the Hans Lollik Member (Helsley, 1960) is renamed the Carrot Bay Member (Figs. 4 and 5).
Possibly correlative strata on Jost van Dyke Island yielded two fossil bearing clasts containing, respectively, a coral fragment and some corroded foraminifera, both reportedly of Paleocene to Eocene age (Helsley, 1960). In addition a carbonate unit in the upper Sharks Bay Member on the north side of Tortola Island (Fig. 4) was reported to contain midEocene algae and foraminifera. Rocks of Maastrichtian age are not known to be present in the British Virgin Islands.

Volcanic stratigraphy in the Virgin Islands concludes with predominantly fine-grained, felsic tuff of

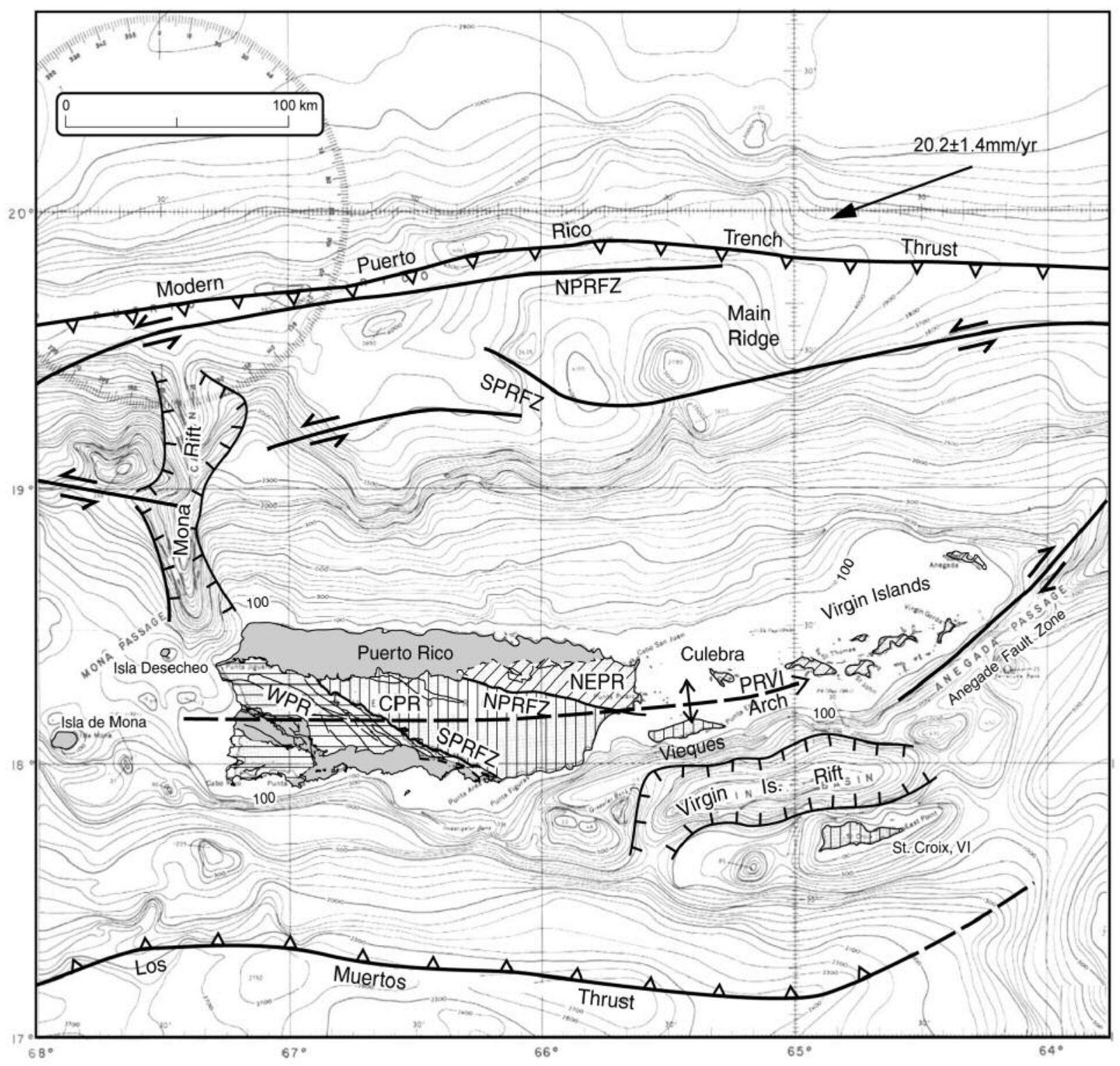

FIGURE 3 Bathymetry and neotectonic elements of the northeast Antilles: NPRSFZ: Northern Puerto Rico Slope fracture zone; SPRSFZ: Southern Puerto Rico Slope fracture zone; Western, central and northeastern Puerto Rico (WPR, CPR, NEPR). PRVI: Puerto Rico - Virgin Is. Microplate. Bathymetry compiled from US Naval Oceanographic charts. 

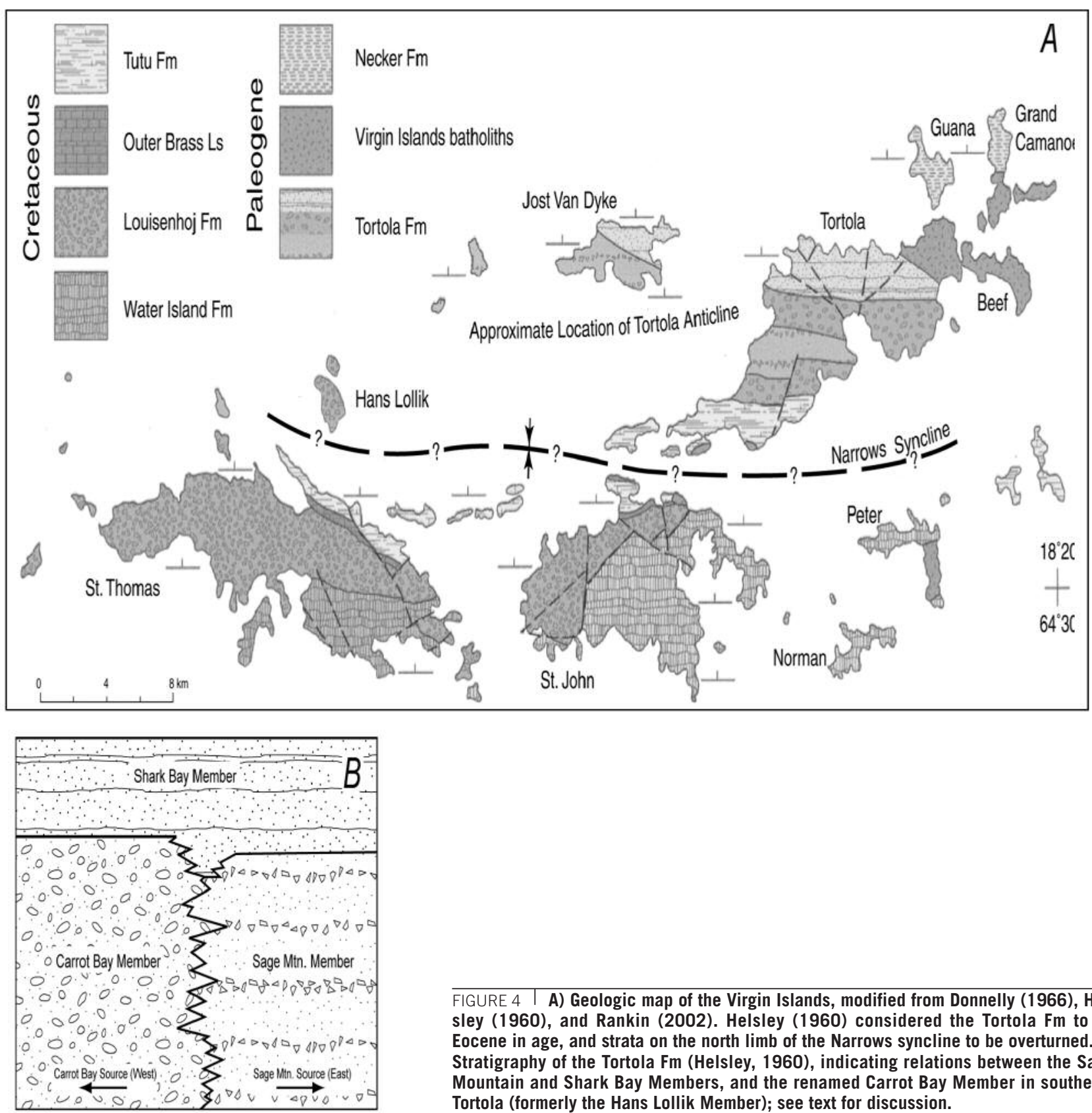

FIGURE 4 A) Geologic map of the Virgin Islands, modified from Donnelly (1966), Helsley (1960), and Rankin (2002). Helsley (1960) considered the Tortola Fm to be Eocene in age, and strata on the north limb of the Narrows syncline to be overturned. B) Stratigraphy of the Tortola Fm (Helsley, 1960), indicating relations between the Sage Mountain and Shark Bay Members, and the renamed Carrot Bay Member in southeast Tortola (formerly the Hans Lollik Member); see text for discussion.

the Necker Fm, which was locally strongly metamorphosed by contact effects associated with the final major magmatic event in the northeast Antilles, intrusion of the calcalkaline Virgin Gorda Batholith. The plutonic rocks, ranging widely in composition from gabbro to adamellite and segregations of granitic pegmatite (Helsley, 1960; Donnelly and Rogers, 1980; Lidiak and Jolly, 1996), have Late Eocene radiometric ages ranging from 39 to $35 \mathrm{Ma}(\mathrm{K} / \mathrm{Ar}$, Cox et al. 1977 and Vila et al., 1986; ${ }^{40} \mathrm{Ar} /{ }^{39} \mathrm{Ar}$, Rankin (2002), consistent with an Eocene age for the Necker Fm (Helsley, 1960).

\section{Puerto Rico}

Dominated by an arched and deeply eroded volcanic core and ringed by mid-Oligocene to Pliocene clastic-carbonate terrestrial through shallow marine sediments (McPhee and Iturralde-Vinent, 1995; van Gestel et al., 1998, 1999; Iturralde-Vinent and McPhee, 1999; McPhee et al., 2003), the island of Puerto Rico consists of three independent tectonic terranes (Figs. 1 and 2), one in the southwest (WPR), another occupying the central and south-central half of the island (CPR), and a third smaller terrane (NEPR) in the north-eastern corner (Schellekens 
et al., 1990; Jolly et al., 1998a; Schellekens, 1998). Maximum thickness of strata in CPR are estimated to total almost 14 km (Jolly et al., 1998a), but additional plutonic underplating during Maastrichtian to Eocene time (Donnelly et al., 1990) produced maximum crustal thickness of up to $30 \mathrm{~km}$ (Boynton et al., 1979). The Southern Puerto Rico Fault Zone (SPRFZ, Glover, 1971), trending southeastward across the western third of the island, forms the CPR-WPR boundary. This mid-Eocene to early Oligocene fault zone (Glover, 1971) effectively truncates geological features in adjacent CPR.

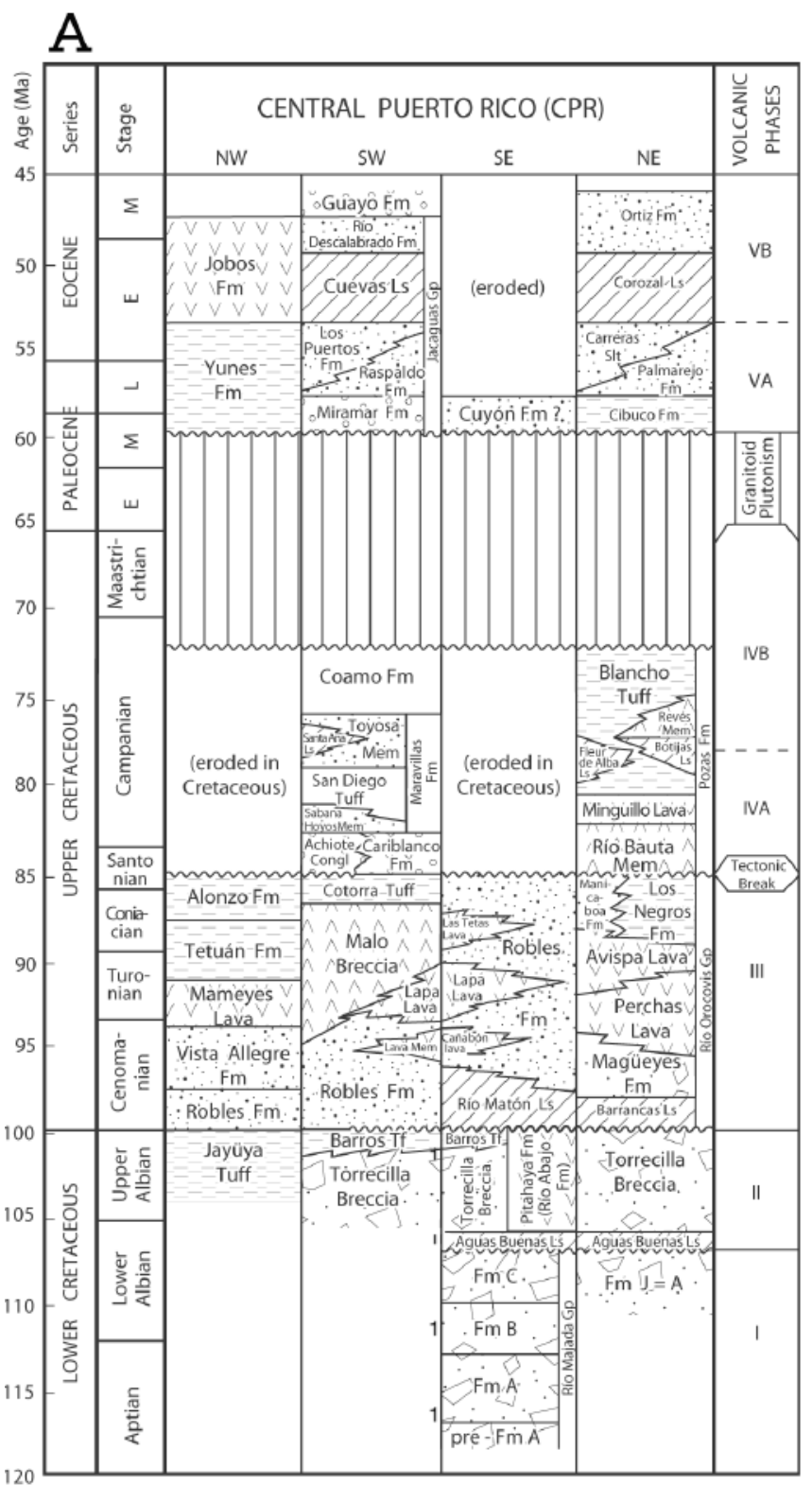

Relative age relations and a detailed stratigraphic framework were firmly established in Puerto Rico by the USGS during a long-term, island-wide mapping project (Bawiec, 2001). CPR and NEPR, to which this paper is restricted, were assembled into their modern configuration during mid-Santonian time (Seiders, 1971) by leftlateral strike-slip faulting along the prominent Cerro Mula Fault zone, a major strand of the Northern Puerto Rico Fault Zone (Glover, 1971). Stratigraphic units on either side of this fault are all plagioclase-augite-bearing, but otherwise are lithologically unrelated prior to mid-San-

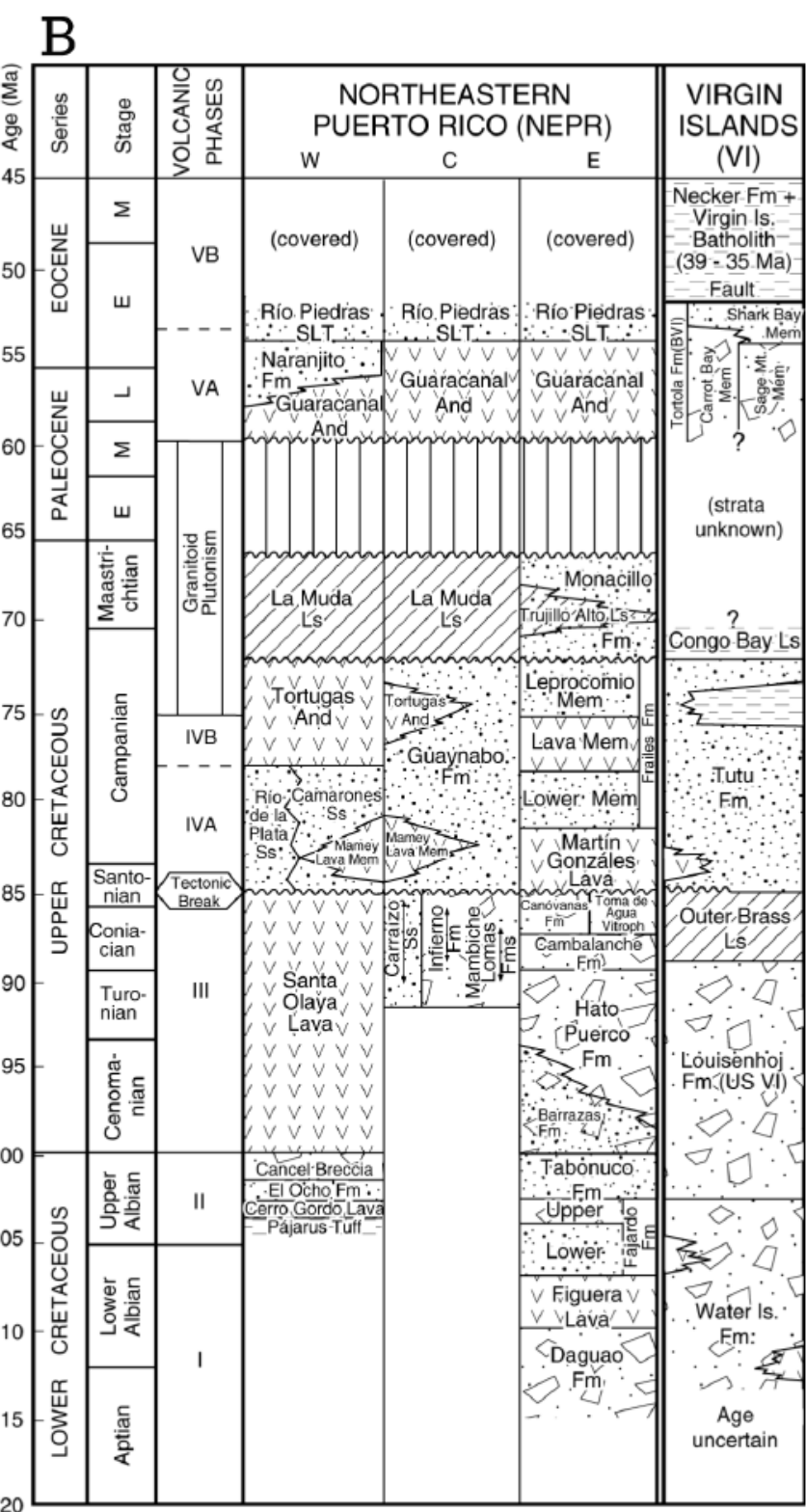

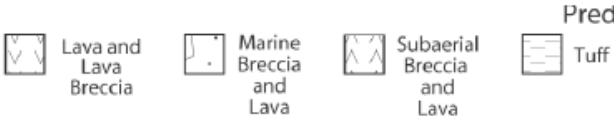

Predominant Lithologies 
tonian time. Total displacement of at least $50 \mathrm{~km}$ is indicated by stratigraphic relations (Pease, 1968); this represents a significant shortening of the arc. Earliest strata in both terranes (Figs. 5 and 6) are broadly dated to the Early Albian (Glover, 1971; Berryhill et al., 1960; Briggs, 1973) and consist of thick sequences of PIA-type, lowLREE/HREE basalts (Schellekens, 1998; Jolly et al., 1998b, 2002). Overlying Cenomanian strata in both CPR and NEPR have higher LREE/HREE, but values in CPR are extremely elevated, reaching levels similar to modern continental margin suites such as the western Philippines, Grenada in the southern Lesser Antilles, and the Aeolian Islands (Fig. 2).

Predominantly east-trending volcanic strata in CPR are subdivided (Figs. 5 and 6; Table 1, see Appendix) into five successive volcanic phases, defined by disconformities associated with reefoidal limestone units that developed on localized topographic highs (Berryhill et al., 1960; Kaczor and Rogers, 1990), including CPRI, CPRII, and CPRIII, from Upper Aptian to Lower Albian, Upper(?) Albian, and Cenomanian to Lower Santonian age, respectively (Fig. 5). Utilizing recognized stratigraphic correlations (Briggs, 1973), CPR volcanic phases are extended into northeast Puerto Rico (NEPRI, NEPRII, NEPRIII; Figs. 5 and 6), where the stratigraphic sequence is entirely conformable (Pease, 1968; Seiders, 1971; Briggs, 1973). Following the mid-Santonian regional strikeslip tectonic event discussed above, calcalkaline volcanism resumed in eastern Puerto Rico, but was intermittent and alternated with extensive granitic plutonism, particularly during Maastrichtian to Paleocene time (Donnelly et al., 1990; Schellekens, 1998). Post-tectonic strata, much of which was subaerial, form belts of similar geochemical composition that extend across the Cerro Mula fault. The rocks are subdivided into two additional volcanic phases, including Upper Santonian to Maastrichtian high-K mostly intermediate volcanic rocks (EPRIV), and Paleocene to mid-Eocene predominantly fine-grained, intermediate to felsic, hornblende-bearing tuff (EPRV). Frost and Schellekens (1991), Larue and Ryan (1998) and Montgomery (1998) reported additional Tertiary strata form extensive subsurface and submarine volcanic basins buried beneath post-volcanic sedimentary cover.

Mattson (1979) suggested the disconformity between phases II and III in CPR, and the unconformity reported by Donnelly (1966) between the Water Island and

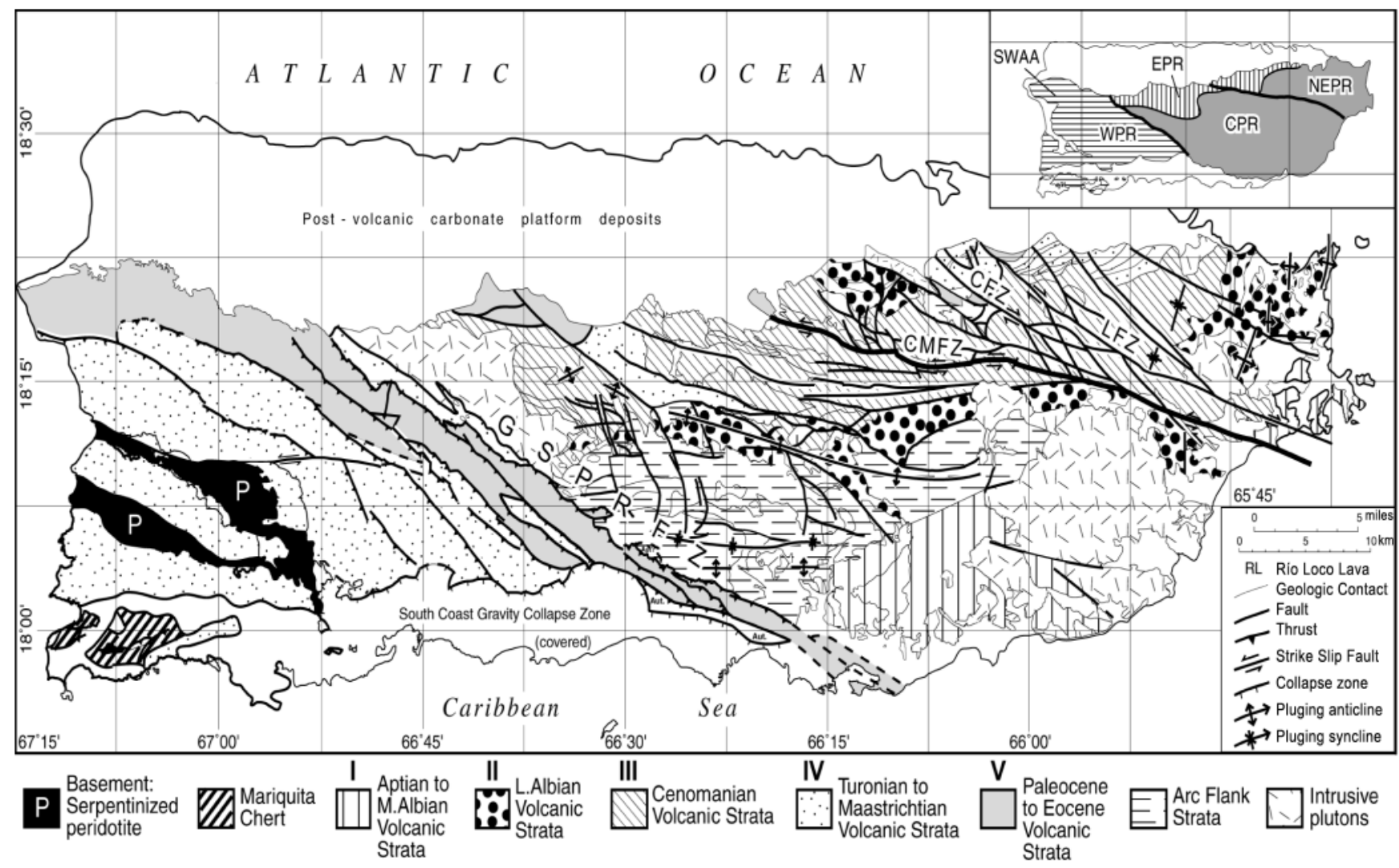

FIGURE 6 Geology of Puerto Rico (modified from Jolly et al., 1998a) illustrating distribution of volcanic phases and structural features. Volcanic phases (I-V) are dated as follows: I: Early Albian (112-105 Ma); II: mid-Albian to Cenomanian (105 to $100 \mathrm{Ma}$ ); III: Cenomanian (100 to $94 \mathrm{Ma}$ ); IV: Turonian to Late Maastrictian (94 to $65 \mathrm{Ma}$ ); V: Paleocene to late mid-Eocene (65 to $45 \mathrm{Ma}$ ). GSPRFZ: Greater southern Puerto Rico fault zone; CMFZ: Cerro Mula fault zone, CFZ: Carraizo fault; LFZ: Leprocomio fault zone. 
Louisenhoj in the Virgin Islands, both represent orogeny resulting from a reversal in polarity of subduction in the Antilles, and this suggestion was incorporated into subsequent Caribbean tectonic models (Lebron and Perfit, 1994; Draper et al., 1996). It is noted, however, that absence of Albian unconformities in NEPR and in the revised Virgin Islands stratigraphic reconstructions of Rankin (2002) is inconsistent with significant tectonism during Albian-Santonian time (112 to $85 \mathrm{Ma}$ ) in the northeastern Antilles, as are observations of Kaczor and Rogers (1990) that, in deep water settings, CPR strata grade conformably across volcanic phase boundaries.

Cretaceous volcanic strata in Puerto Rico contain eroded remnants of numerous strato-volcanoes, individu-

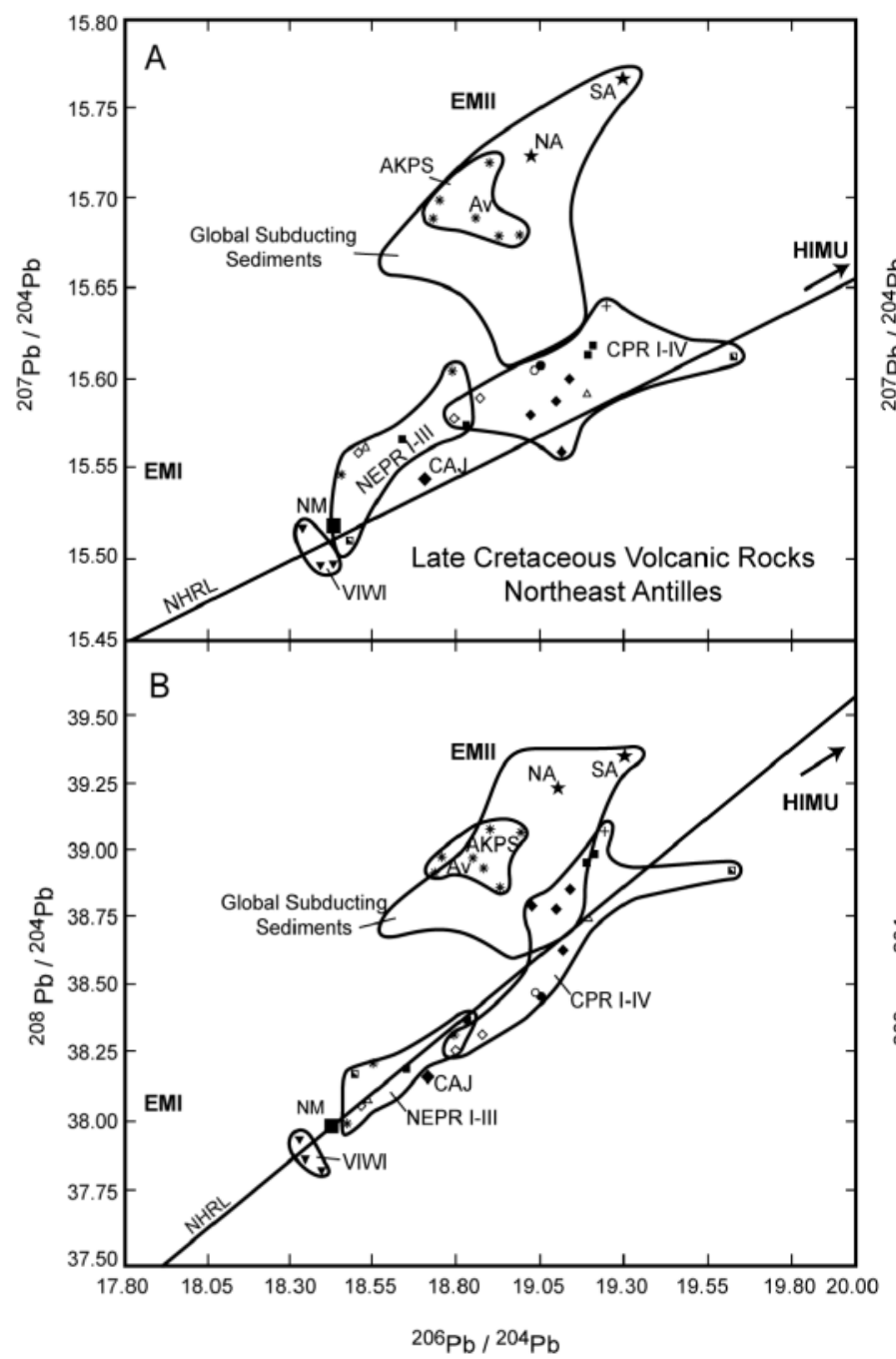

ally marked by localized accumulations of lava and lava breccia several kilometers thick. The volcanic centers tend to be oriented in chains along east-southeast trends representing principal volcanic axes, physiographically analogous to modern volcanic arc fronts. In CPR geographic positions of successive Cretaceous volcanic chains migrated 5 to $15 \mathrm{~km}$ northward. Abundant flank strata, deposited on the back-arc side of the principal volcanic axis during phases CPRIII and CPRIV, are widely preserved in south-central Puerto Rico (Fig. 6).

\section{Hispaniola}

Although Hispaniola is located across Mona Passage and therefore lies outside the northeast Antilles as

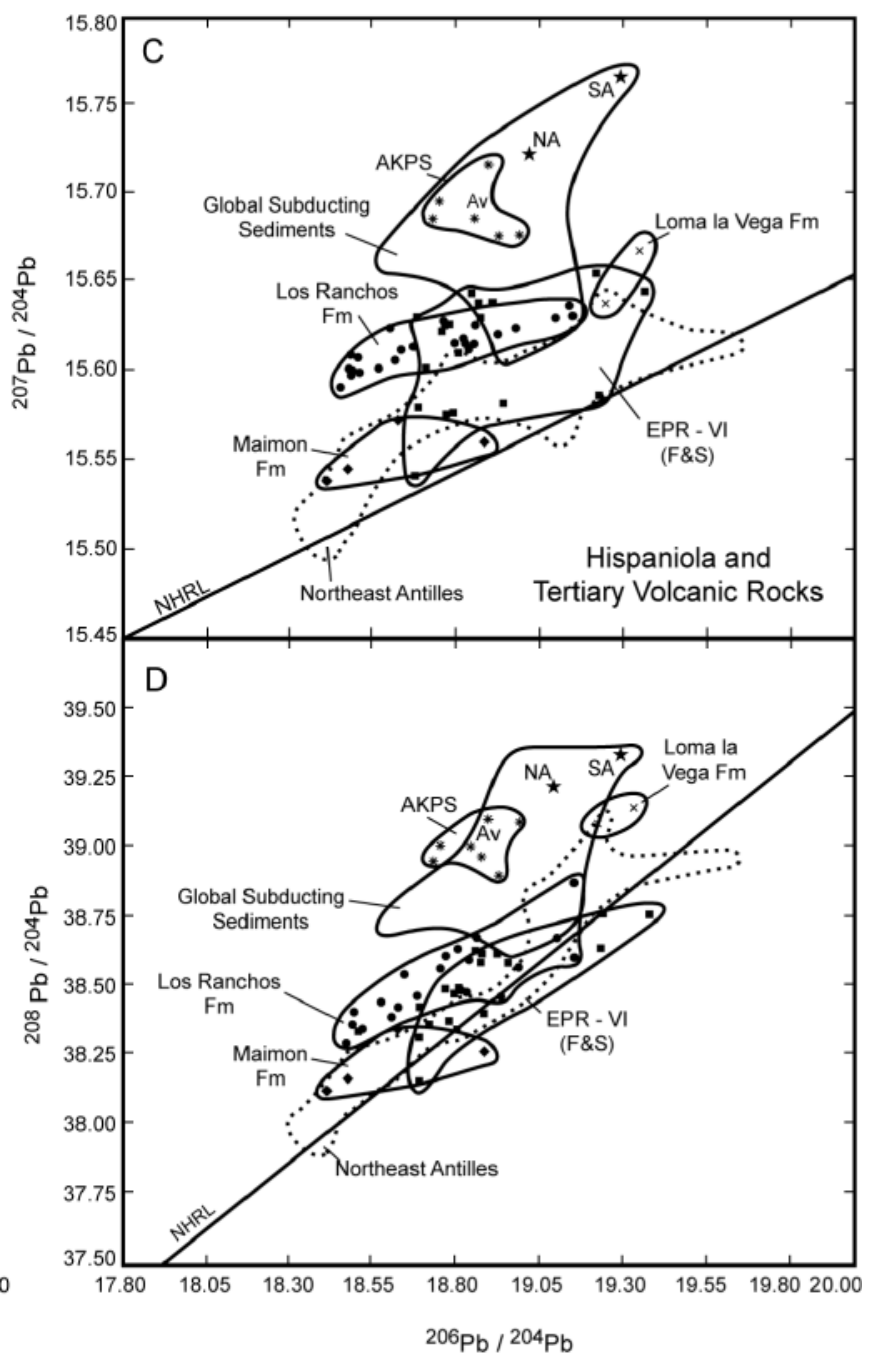

FIGURE 7 206 Pb/204Pb, 207Pb/204Pb and ${ }^{208} \mathrm{~Pb} / 204 \mathrm{~Pb}$ in the northeast Antilles. A and B) Northeast Antilles. C and D) Hispaniola and Puerto Rican Tertiary basalts (Frost and Schellekens, 1998). Av. AKPS: average Atlantic Cretaceous pelagic sediment; VIWI: Water Island Fm., Virgin Islands (data from Donnelly, 1978); CPR: central Puerto Rico; NEPR: northeast Puerto Rico block (sample locations given in Jolly et al., 1998b); I, II, III, IV, V: volcanic phases; CAJ: pre-arc MORB-like basalt from Western Puerto Rico, Global, northern (NA) and southern (SA) Lesser Antilles sediment from Plank and Langmuir (1997); Northern Hemisphere Reference Line (NHRL), enriched mantles EMI, EMII, and HIMU, and NM (depleted MORB) are from Hart (1984); Hispaniola data sources as follows: Los Ranchos Fm, Cumming and Kesler (1987); Maimon Fm, Horan (1995); Loma La Vega Fm, Lebron and Perfit (1994). 
defined here (Figs. 1 and 2), the stratigraphic sequence is similar and is therefore relevant because it provides insight into lateral correlations with major islands of the Greater Antilles. The Mesozoic basement in central Hispaniola consists of the basaltic Duarte Complex and associated Loma Caribe peridotite, considered to represent a preserved Jurassic to Late Cretaceous oceanic crustal segment (Lewis et al., 1999, 2002). In addition to extrusive volcanic rocks, Lapierre et al. (1997, 1999) recognized a separate mafic intrusive phase of Albian age within the Duarte sequence, interpreted to record an early oceanic plateau event. There is wide consensus that the Duarte terrane was obducted by north-directed thrusting onto early island arc strata along a north-dipping subduction zone due to collision between the developing arc and an approaching oceanic plateau. However, there is disagreement regarding timing of the overthrusting event. Draper et al. (1996) viewed tectonism as Albian in age on the basis of structural fabrics in the Early Albian Los Ranchos Fm that are not reproduced in younger Cenomanian strata, and correlated the event with Albian unconformities reported in the Virgin Islands and central Puerto Rico (see also Burke, 1988; Pindell and Barrett, 1990; Lebron and Perfit. 1994; Lewis et al., 1999, 2002). Instead, Lapierre et al. (1997) correlated Duarte strata with basalts of the CaribbeanColumbian Cretaceous Basalt Plateau (CCBP, 92-74 Ma, Hauff et al., 1997, 2000; Kerr et al., 1999, 2002), and suggested obduction was post-Santonian.

Initial island arc strata in Hispaniola include the PIA-type Amina, Maimon and Los Ranchos Fms. Of these, the Los Ranchos has been radiometrically dated to $110 \mathrm{Ma}$ (U-Pb, zircons, Kesler and Campbell, 2005). The Maimon Fm, which contains boninitic basalts interlayered with low-K IAB, is unique in the Antilles outside of Cuba, but Los Ranchos basalts are similar in composition to PIA-type volcanic rocks (Lewis et al., 2002). Cumming and Kesler (1987) and Kesler and Campbell (in press) report relatively elevated $\mathrm{Pb}$ isotope ratios in Los Ranchos basalts from Hispaniola (Figs. 7C and 7D). Succeeding post-Albian calcalkaline strata in Hispaniola include the Cenomanian Tireo Group and Campanian to Maastrichtian Loma La Vega Fm (Lewis et al., 2002).

\section{ANALYTICAL DATA AND GEOCHEMICAL PARAMETERS}

\section{Analytical data base}

New major and trace element data for 18 representative samples from the Virgin Islands and Puerto Rico performed for this project are presented in Table 2 (see Appendix). These include ten Atlantic Late Cretaceous pelagic sediments (AKPS), and 8 representative island arc basalts from the Virgin Islands (10), NEPR (10), CPR (12), and EPR (2). To minimize effects of crystal fractionation and crustal assimilation, geochemical samples are restricted to basaltic end-members with $\mathrm{SiO}_{2}<55 \%$; frac-
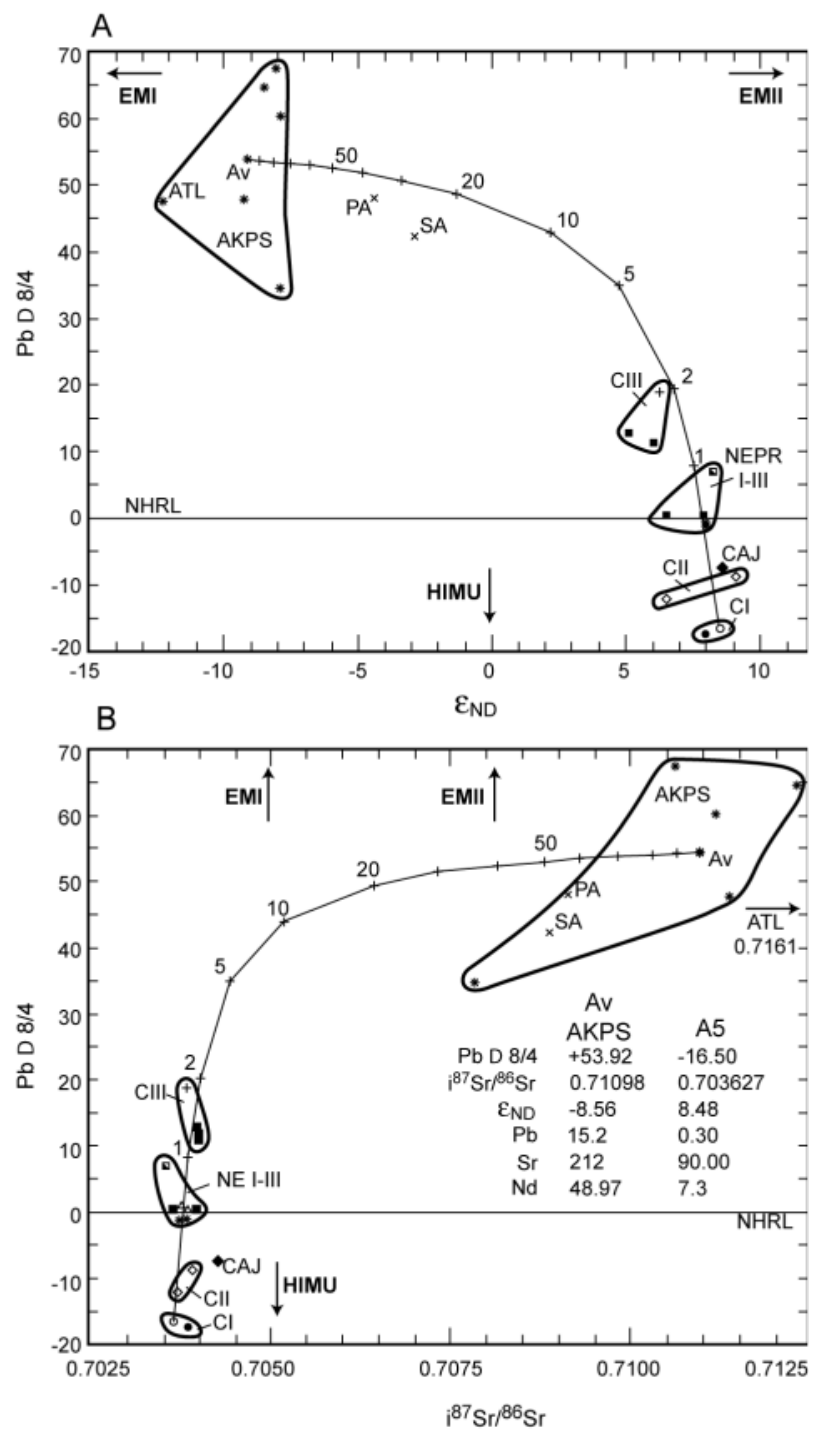

FIGURE 8 Isotope mixing between hypothetical wedge sources and average Atlantic Cretaceous pelagic sediment (AKPS). Hyperbolic curves with mixing intervals represent results of mixing calculations. Fields of analyzed samples are identified as follows: C: central tectonic block; NE: northeast tectonic block; I, II, III, IV, $V$ represent Puerto Rican volcanic phases. A) $\varepsilon_{\mathrm{Nd}}-\Delta \mathrm{Pb}^{8} / 4$ values. End-members (Table 2, see Appendix) include 1) hypothetical source of sample A-5 (see Jolly et al., 2002) representing the composition of the wedge plus slab-derived aqueous fluid with a minimal sediment component. PA and PAWMS: carbonate-rich pelagic sediment (Hole et al., 1984); Atl and SA: North and south Atlantic low-carbonate pelagic sediment from Ben Othman et al. (1985). B) $i^{87} \mathrm{Sr} /{ }^{86} \mathrm{Sr} \Delta \mathrm{Pb}^{8} / 4$. Calculated mixing curves are consistent with mixing between the corrected source of Formation A basalts and up to $2 \%$ pelagic sediments (AKPS), in addition to sediment present in the starting basalt (range between 0.5 and $4 \%$, see Fig. 13A). Compositions of end-members are listed at right. 
tionates and other intermediate to felsic end-members are considered elsewhere. Sample preparation was performed in stainless steel and mullite vessels to insure minimal trace element contamination. Major element ICP-ES and trace element ICP-MS analyses were performed, following $\mathrm{LiBO}_{2}$ fusion, at Acme Analytical Laboratories, Vancouver, Canada. Duplicate analyses and deviations from geochemical standards reveal precision to be within 1 to $5 \%$ of the amount present or better for most trace elements. Geochemical study in this investigation is restricted to components that are stable in the presence of aqueous, chloride brines, including REE, HFSE, and Th-U (Pearce and Parkinson, 1993). Hence, effects of aqueous fluids on abundances of soluble large-ion lithophile elements (LILE, Rb, Ba, U, K, Sr and $\mathrm{Pb}$ ) during magma generation and evolution are not considered.

Jolly et al. (1998b) summarized isotope analytical techniques and precision limits. Duplicate isotope analyses of leached and unleached samples revealed no significant differences. Comprehensive isotope data from Puerto Rican Island arc rocks, including $\varepsilon_{\mathrm{Nd}}, \boldsymbol{i}^{87} \mathrm{Sr} /{ }^{86} \mathrm{Sr}$, and $\mathrm{Pb}$ isotope ratios are listed in Jolly et al. (1998, 2001); additional $\mathrm{Pb}$ isotope ratios from Paleocene and Eocene volcanic and plutonic rocks are given in Frost and Schellekens (1998). Pb data from the Virgin Islands consist of three analyses from the Water Island Fm (Donnelly et al., 1971; a fourth anomalously low analysis is omitted).

\section{Atlantic Cretaceous pelagic sediment (AKPS)}

The preserved pre-arc basement in WPR consists of serpentinized peridotite and Jurassic to Late Cretaceous oceanic crust associated with radiolarian chert of Pacific provenance. The presence of these rocks is consistent with generation of the Antilles island arc through southdipping subduction as the Pacific (Farallon) Plate swept through the Caribbean basin, over-riding the young protoAtlantic ridge (Donnelly, 1989; Pindell and Barrett, 1990). Consequently, pelagic sediment most closely resembling that subducted by the advancing Antilles arc is preserved within the Atlantic basin north of the modern Puerto Rican Trench Thrust (Fig. 1). Full major and trace element geochemical data, and estimated paleontologic ages (Donnelly, 1978; Donnelly et al., 1978), for ten representative samples of Atlantic Cretaceous pelagic sediment (AKPS) from this reservoir, including five each from Deep Sea Drilling Project sites 105 and 417D in the eastern North Atlantic (Donnelly et al., 1978), are listed in Table 2 (see Appendix). Isotope data for eight of the samples are given in Table 3 (see Appendix). The average trace element composition of this sample set (Table 4, see Appendix), consisting of six carbonates and four claystones, in conformity with approximate abundances of rock types recovered from the Atlantic basin, is utilized to represent the subducted sediment component in geochemical models presented in this paper. It is recognized, however, that additional, relatively thick sequences of pre-arc, continental margin-type pelagic sediments, such as those in the blueschist terrane of the Samana Peninsula, northern Hispaniola (Joyce, 1990), were probably also involved in the subduction process, particularly along lateral extremities of the arc.

\section{Melting models}

Mineralogical modes utilized in calculations, representing a spinel lherzolite N-MORB-type source (fertile MORB mantle [FM] in the terminology of Pearce and Parkinson, 1993), consist of $57.5 \%$ olivine (ol), $27.0 \%$ orthopyroxene (opx), $12.5 \%$ clinopyroxene (cpx), and $3.0 \%$ spinel (McKensey and O'Nions, 1991). Phases are inferred to disappear from the source at constant rates during melting, such that orthopyroxene melts incongruently to olivine during early stages of fusion. Rates of phase disappearance adopted include cpx, 25\%; opx, 40\%; Al-spinel, 80\% (Pearce and Parkinson, 1993). The trace element composition of FM, and mineral/melt trace element partition coefficients (D-values) for ultramafic melts are from Bédard (1999). Trace element concentrations utilized in calculations are corrected for ol fractionation during magmatic assent to $\mathrm{MgO}=9.0 \%$ from $\mathrm{MgO}-\mathrm{Yb}$ abundances, according to the method of Pearce and Parkinson (1993).

Johnson and Dick (1992) described mantle peridotite from modern ridge environments presumed to represent residua from MORB-type melting, and demonstrated that these rocks are less depleted in certain incompatible elements than calculated residua. In their models of MORB melting they adopted open system fractional melting, with the caveat that pooled melts were continuously reequilibrated with the mantle as they percolated upward through the melting column. Pearce and Parkinson (1993) also utilized fractional melting models, assuming the system to be closed, and refined the models by simulating retention of small quantities of melt in the residua equivalent in volume to porosity, which, according to relations between $\mathrm{Zr}$ contents and modal clinopyroxene in depleted peridotite (fig. 8 of Pearce and Parkinson, 1993), ranges from $<0.5$ to a maximum of about $3 \%$. In models presented here, upward re-equilibration of melts with the mantle and melt retention by the residue are both simulated by combining fractional melting (Shaw, 1970) with corrections for trapped melt. Trapped melt is treated as a separate phase with a partition coefficient (D-value) of 1.0, according to the method of Pearce and Parkinson (1993). This procedure has the effect of increasing bulk distribution coefficients for all incompatible elements, but especially $\mathrm{Th}, \mathrm{Nb}, \mathrm{La}, \mathrm{Ce}, \mathrm{Pr}$, and $\mathrm{Nd}$. Melt compositions are similar regardless of corrections, but residua vary widely, 
depending on proportions of trapped melt; a median value of $1.0 \%$ trapped melt retention is utilized in models. Residual cpx modes obtained in the models produce slopes matching theoretical residues when plotted against abundances of key trace elements (fig. 5 of Pearce and Parkinson, 1993). In multiple component melting models involving pelagic sediment (Nicholls et al., 1994) or an ocean island basalt component, additives are treated as $100 \%$ melt fractions and combined with the source.

\section{Nd-Sr-Pb ISOTOPE GEOCHEMISTRY}

\section{Isotope ratios}

Initial $\mathrm{Nd}$ isotope ratios in early Antilles volcanic rocks resemble MORB (denoted CAJ in Figs. 7 and 8; Jolly et al., 1998b), but become gradually more enriched in successive volcanic phases (Fig. $8 \mathrm{~A}$ ). $\varepsilon_{\mathrm{Nd}}$-values of early units range from about 8.5 to 6.5 , while CPRIII averages 6.5 . $\boldsymbol{i}^{87} \mathrm{Sr} /{ }^{86} \mathrm{Sr}$ (Fig. 8B) broadly approach or overlap compositions of altered WPR and unleached Atlantic Mesozoic MORB, both of which have elevated radiogenic Sr with respect to modern MORB due to seafloor alteration (Jahn et al., 1980). CPRI basalts have lowest $i^{87} \mathrm{Sr} /{ }^{86} \mathrm{Sr}$, ranging between 0.7033 and 0.7041 ; while values in CPRIII average about 0.7039 , the total range is large, from 0.7035 to 0.7044, partly overlapping earlier units (Fig. 8B). More enriched modern island arcs have similar wide ranges in radiogenic $\mathrm{Pb}$ (Elliot et al., 1997). $\mathrm{Pb}$ isotope ratios, following patterns similar to $\mathrm{Nd}$-isotopes (Figs. 7a and b; Table 4, see Appendix), form fields subparallel to the northern hemisphere reference line (NHRL; Hart, 1984). ${ }^{206} \mathrm{~Pb} /{ }^{204} \mathrm{~Pb}$ increases gradually from depleted MORBlike values (18.3 to 18.4 ) in the Virgin Islands (Donnelly et al., 1971), to between 18.5 to 19.0 in NPR, and finally to elevated levels ranging from 18.8 to over 19.5 in CPR, consistent with systematic west to east increase in the proportion of a U-Pb-enriched HIMU component (Hart, 1984) in the mantle source. Superimposed on this compositional shift are additional, somewhat incoherent variations of ${ }^{207} \mathrm{~Pb} /{ }^{204} \mathrm{~Pb}$ and ${ }^{208} \mathrm{~Pb} /{ }^{204} \mathrm{~Pb}$, indicating elevated radiogenic $\mathrm{Pb}$ contributed by an enriched component, such as pelagic sediment or an EMI-type component (Figs. 7A and 7B). Since ${ }^{208} \mathrm{~Pb} /{ }^{204} \mathrm{~Pb}$ is relatively less affected by $\mathrm{U}-\mathrm{Pb}$ systematics, $\mathrm{Pb} \Delta^{8} / 4$-values (Table 1 , see Appendix), representing deviation of ${ }^{208} \mathrm{~Pb} /{ }^{204} \mathrm{~Pb}$ from the NHRL with respect to ${ }^{206} \mathrm{~Pb} /{ }^{204} \mathrm{~Pb}$ (Hart, 1984), indicate magnitude of $\mathrm{Pb} \Delta^{8} / 4$ is lowest in CPRI-II, ranging from 0 to -20 (Fig. 8), and ranges as high as +10 to almost +20 in CPRIII. In NEPR, compositions cluster along the NHRL with values ranging from +5 to -25 (Fig. 8 ).

Post-Santonian Puerto Rican island arc basalt (EPRIV-V) has also elevated radiogenic $\mathrm{Pb}$ (Frost and Schellekens, 1991; Frost et al., 1998; Figs. 7C and 7D),

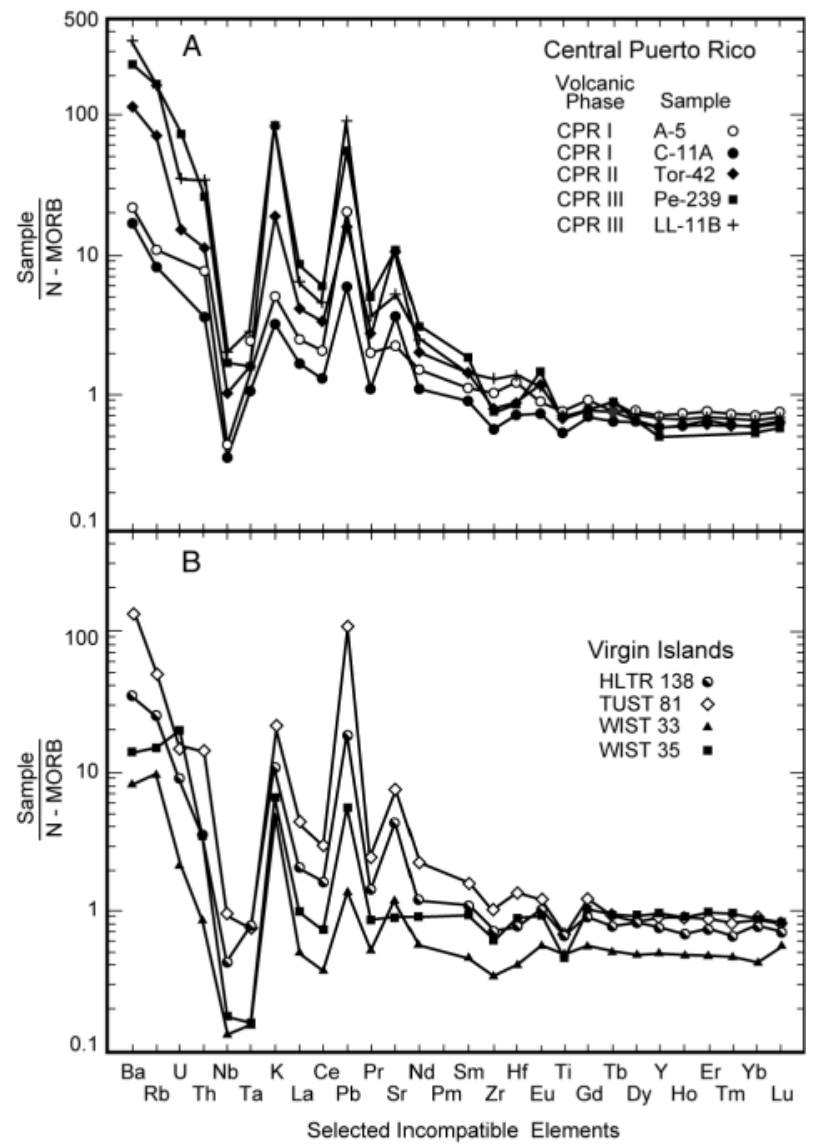

FIGURE 9 | N-MORB-normalized incompatible element patterns in representative arc basalts from CPR $(A)$ and the Water Is. Fm in the Virgin Islands (B). VI basalts include representatives from the Tutu Fm (TU), Tortola Fm (TR), and the Water Is. Fm, WI (including a felsic endmember or keratophyre, WIST35). Full geochemical data for selected basalts from this list and additional basalts are presented in Table 2 (see Appendix). Normalization factors and sequence are modified from Sun and McDonough (1989); more incompatible elements are at right.

with ${ }^{206} \mathrm{~Pb} /{ }^{204} \mathrm{~Pb}$ between 18.4 to 19.4 , broadly overlapping fields for CPRII and CPRIII. ${ }^{208} \mathrm{~Pb} /{ }^{204} \mathrm{~Pb}$ fields for younger EPR volcanic rocks are aligned along NHRL, while ${ }^{207} \mathrm{~Pb} /{ }^{204} \mathrm{~Pb}$ has a broad elevated range up to 15.65 . In Hispaniola, the Albian Maimon Fm (Horan, 1995) broadly overlaps NEPR fields, but other units have elevated $\mathrm{Pb}$ isotope ratios compared to the northeast Antilles. For example, ${ }^{207} \mathrm{~Pb} /{ }^{204} \mathrm{~Pb}$ in Los Ranchos lavas exceeds measured values in CPR. Similarly values for ${ }^{207} \mathrm{~Pb} /{ }^{204} \mathrm{~Pb}$ and ${ }^{208} \mathrm{~Pb} /{ }^{206} \mathrm{~Pb}$ in the Campanian to Maastrichtian Loma La Vega Fm equal or exceed CPRIII (Figs. 7C and 7D).

\section{Isotope mixing models}

Although the absolute composition of the mantle source is unknown, the low- $\mathrm{Pb} \Delta^{8} / 4$ isotope signature of early CPRI arc basalts in the northeast Antilles is similar to pre-volcanic Cretaceous MORB (Cajul basalt CAJ-103 in Figs. 7A and 7B, 8A and 8B), consistent with a MORB-like source (Jolly et al., 1998b). Hence, CPRI 
basalts have a limited sediment component, and an estimate of the proportion of sediment incorporated by more radiogenic CPRIII lavas is obtained from a calculated mixing line with end-members that include 1) the inversion source $(f=0.25)$ of a CPRI basalt (sample A-5) and 2 ) the average AKPS composition (end members are list-
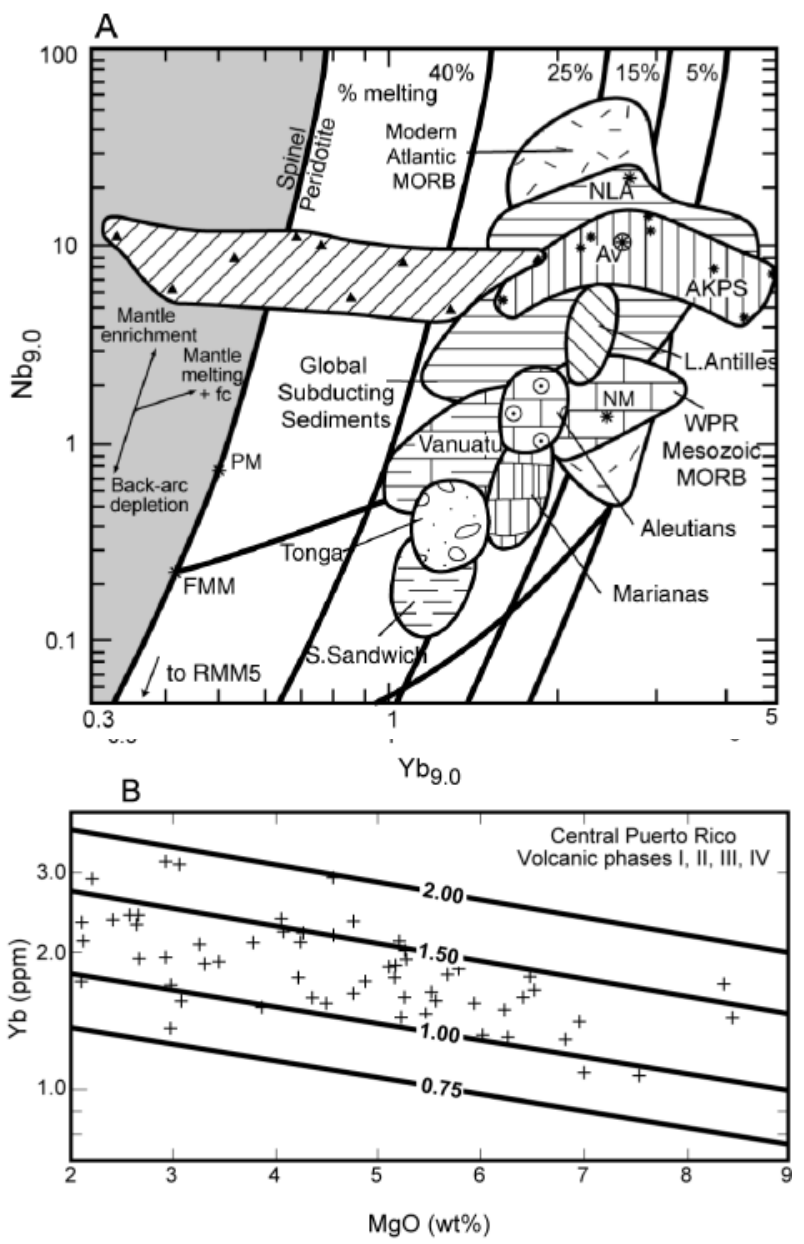

\begin{tabular}{l|ll}
\hline FIGURE 10 & A) $\mathbf{N b}$ - Y melting grid consisting of a) trajectories
\end{tabular} representing fractional fusion of FM (fertile MORB mantle of Pearce and Parkinson [1993], as modified by Bédard [1999]) and RMM5 (residue of $5 \%$ melt of FM); and b) contours for 5, 15, 25 and $40 \%$ melting. PM, primitive mantle, NM, N-MORB of Sun and McDonough (1989), Av. AKPS, average Atlantic pelagic sediment. Selected modern island arc suites with relatively flat N-MORB-normalized HREE patterns include the following: Aleutians (Romick et al., 1990); Northern Lesser Antilles, Davidson (1986); Marianas, Woodhead et al. (1998); South Sandwich, Cohen and O'Nions (1982); Tonga, Ewart and Hawkesworth (1987); and Vanuatu (Peate et al., 1997). Are also included modern North Atlantic MORB (Dosso, et al., 1993) and WPR Mesozoic MORB (Schellekens et al., 1990; Jolly et al., 1998a), the field of Atlantic Cretaceous pelagic sediment (AKPS, Table 2, see Appendix), NLA, northern Lesser Antilles sediment and global subducting sediment (Plank and Langmuir, 1997), and volcanic glass representing slab melt from sub-arc peridotite xenoliths in the Philippines (Schiano et al., 1995). B) Covariation of $\mathrm{MgO}-\mathrm{Yb}$ concentrations in analyzed basalts $\left(\mathrm{SiO}_{2}<55 \%\right)$ from central Puerto Rico. Diagonal lines, which represent $\mathrm{Yb}$ concentrations extended from $\mathrm{MgO}=$ 9.0\% to lower MgO concentrations along tracks parallel to the data field of CPR volcanic phases I, II, and III, illustrate derivation and uncertainty of fractionation corrections. ed in Fig. 8B). In $\mathrm{Pb} \Delta^{8} / 4-\boldsymbol{\varepsilon}_{\mathrm{Nd}}$ and $\mathrm{Pb} \Delta^{8 / 4}-\boldsymbol{i}^{87} \mathrm{Sr} /{ }^{86} \mathrm{Sr}$ plots, Puerto Rican data concentrate along or overlap the mixing lines, with CPRIII concentrating at the $2 \%$ level with respect to sample A-5, broadly similar to levels in modern arcs (Ellam et al., 1988, Ellam and Hawkesworth, 1988). This estimate represents a minimum value, since it does not include the sediment component of the CPRI starting basalt

\section{Incompatible trace element geochemistry}

MORB-normalized incompatible trace element spectra reveal that Puerto Rican volcanic rocks, like Cretaceous lavas and associated plutonic rocks from other islands of the Greater Antilles (Donnelly, 1989; Lebron and Perfit, 1994; Lidiak and Jolly, 1996), are uniformly over enriched in LILE with respect to LREE, moderately enriched in LREE and Th, and strongly depleted in HFSE, all fundamental features of island arc associations (Fig. 9). The most depleted rocks in the northeast Antilles include the Water Island and Louisenhoj Fms in the Virgin Islands, which have normalized slopes ranging from slightly enriched to moderately depleted (Fig. 9). In Puerto Rico, the complete range of compositions is represented in CPR (Fig. 9). Basal basalts from Formation A (CPRI, Fig. 9) are the least enriched in incompatible elements, and have lowest LILE/HFSE and HFSE/HREE, as well as lowest LREE/HFSE and LREE/HREE. Values of all these ratios increase in succeeding volcanic phases, reaching maximum levels in high-K basalts from the Perchas Fm in CPRIII.

\section{$\mathrm{Nb}-\mathrm{Yb}$ (corrected for olivine fractionation to crustal levels to $\mathrm{MgO}=9.0 \%$ )}

The absolute concentration of $\mathrm{Yb}$ in mantle basalts reflects the degree of fusion in a peridotite source, while $\mathrm{Nb}$ abundance is proportional to relative degree of incompatible element source enrichment (Pearce and Parkinson, 1993). Consequently, covariation of this element pair, when corrected for ol-fractionation, can potentially provide insight into both melting processes and source compositons in the northeast Antilles. For this purpose, a calculated $\mathrm{Yb}-\mathrm{Nb}$ melting grid, assembled from spinel peridotite melting curves for both FM and RMM2 (the residue of a $5 \%$ melt of FM) and contours representing 40, 25, 15, and 5\% melting (Pearce and Parkinson, 1993), is presented in Fig. 10A. Actual mantle compositions and modes vary widely (Pearce and Parkinson, 1993) from idealized values adopted for model calculations. Despite the limitations, however, generalized melting grids provide a standardized framework that permits meaningful intra- and inter-arc comparison. For instance, N-MORB (denoted NM, Sun and McDonough, 1989), modern Atlantic MORB (Dosso et al., 1993) and WPR Mesozoic 
MORB (Schellekens et al., 1990; Jolly et al., 1998a and b) concentrate in a band, between the 5 and $15 \%$ melting contours, indicative of relatively low degrees of melting compared to selected island arc basalts (Fig. 11A). The models also reveal that arc basalts have compositions intermediate between mantle compositions and pelagic sediment, as characterized by global subducting pelagic sediment (Plank and Langmuir, 1997) and Atlantic Cretaceous pelagic sediment (AKPS).

In the Virgin Islands, $\mathrm{Yb}-\mathrm{Nb}$ data subdivide basalts $\left(\mathrm{SiO}_{2}<55 \%\right)$ from the Water Island Fm into several interefingering sub-units, including a high-Yb MORBlike basalt, low-HFSE basalts, and a two sampl,es of sheeted dikes from St. John (Fig. 11A). Fields for all but one of these plot below the FM melting trajectory, indicating slightly depleted $(\sim 2 \%)$ source compositions and a relatively small incompatible element-enriched component (i. e., pelagic sediment). Water Island basalts tend to be slightly more depleted in $\mathrm{Nb}$ than samples from both the Louisenhoj and Tortola Fms. A slightly enriched source is indicated for high LREE basalts. In general, there is a wide range in $\mathrm{Yb}$, reflecting considerable variation in degree of melting, but most samples are concentrated along the $25 \%$ melting contour.

Corrected $\mathrm{Yb}$ concentrations in Puerto Rico overlap the Virgin Islands, consistent with a wide range in degree of melting from a maximum of almost 40 to less than $15 \%$ in early basalts, but $\mathrm{Nb}$ abundances in Puerto Rico are much more variable and in most flows more elevated than their counterparts in VI. Data from NEPR cluster along the FM melting trajectory (Fig. 11B), consistent with an FM-like source composition with relatively little sediment. In comparison, $\mathrm{Nb}$ abundances increase from an average of less than 1 to over 3 ppm between CPRI and III (Fig. 11C). Taken together the data form a broad vector with a trajectory directed toward average AKPS, consistent with a spectacular increase in the proportion of pelagic sediment contributed to the melt in CPR compared to NEPR and VI. Strata from the Virgin Islands and eastern Puerto Rico dating between Maastrichtian and mid-Eocene time resemble CPRIII.

\section{Multiple component melting models}

Absolute degree of melting in arc settings is controversial (Plank and Langmuir, 1997; Davies and Stephenson, 1992). Johnson and Dick (1992) and Pearce and Parkinson (1993) argued that island arc melting processes are not analogous to those involved in generation of MORB magmas. Differences arise from hydration of the wedge by fluids emanating from the subducting slab in arc settings, and from resultant increased buoyancy of hydrated peridotite, which together lead to extensive decompression fusion within the wedge. Together, these two complementary processes

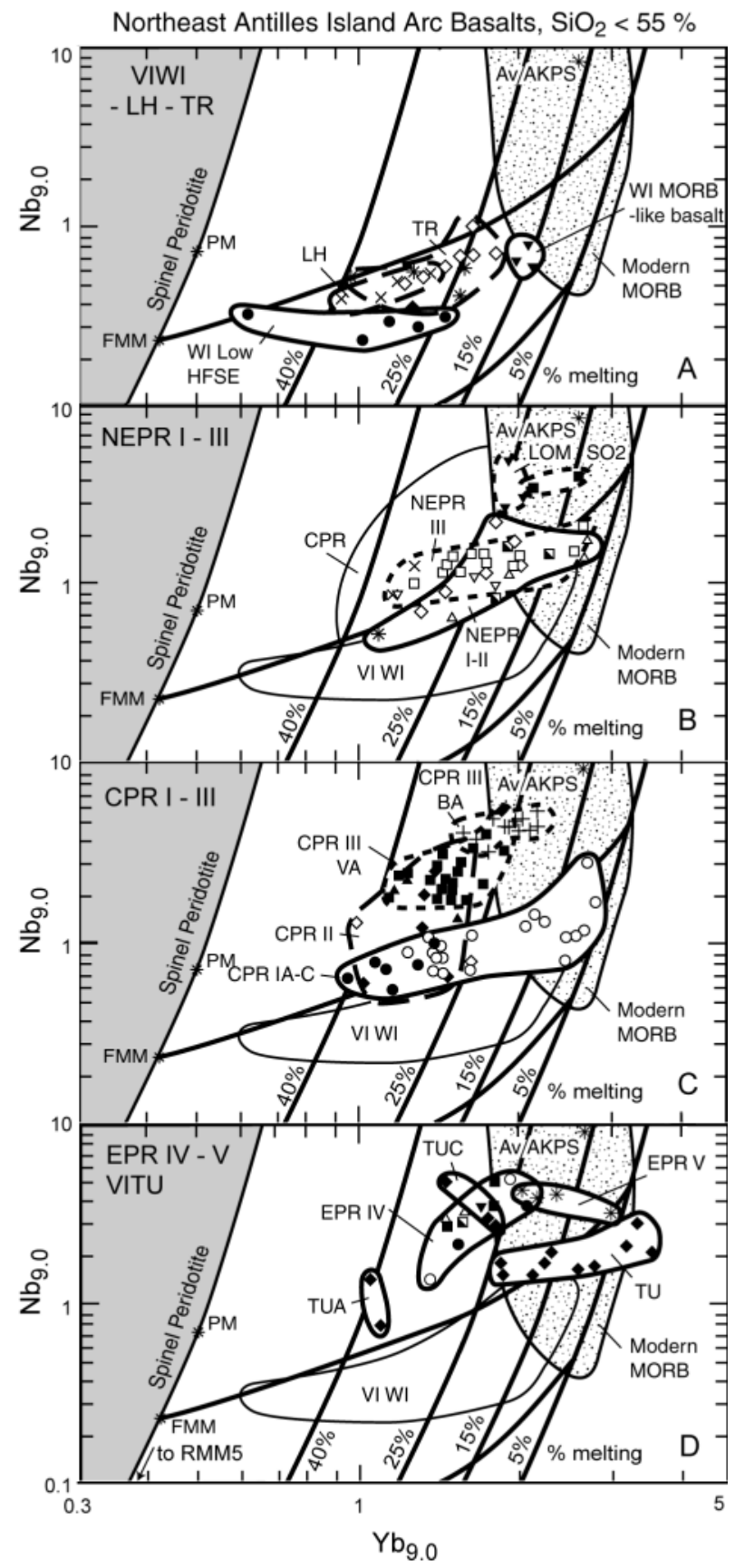

FIGURE 11 Covariation of $\mathbf{N b}$ and $\mathbf{~} \mathbf{b}$ in northeast Antilles basalts $\left(\mathrm{SiO}_{2}<55 \%\right)$, corrected for ol fractional crystallization during elevation from mantle to crustal levels to $\mathrm{MgO}=9.0 \%$ (Fig. 10B); melting grid is from Fig. 10A. A) Virgin Islands: WI: Water Island Fm; LH: Louisenhoj Fm; TU: Tutu Fm; TR: Tortola Fm; other symbols as in Table 1 (see Appendix). Water Island plagiorhyolites (denoted VIWI-4 and 5) represent compositions of crustal contaminants in Antilles volcanic rocks. B) Central Puerto Rico volcanic phases CPRI- III, BA: back arc; VA: principal volcanic axis. C) Northeast Puerto Rico volcanic phases NEPRI-III. D) Eastern Puerto Rico volcanic phases EPRIV - V. PM represents the primitive mantle composition of Sun and McDonough (1989); modern (Atlantic) MORB from Dosso et al. (1993); fc, fractional crystallization. 


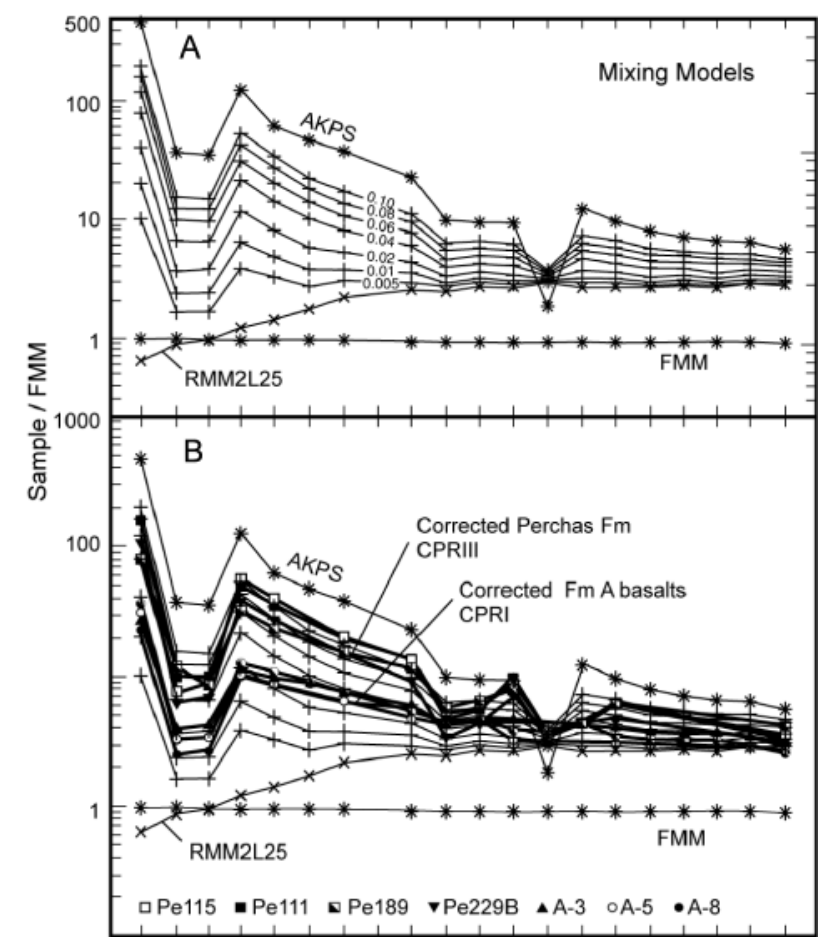

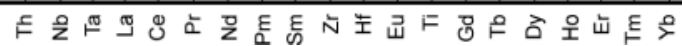

\begin{tabular}{l|l}
\hline FIGURE 12 & Mixing between RMM2 and proportions of AKPS produces
\end{tabular} melts (A) with chondrite-normalized incompatible element patterns similar (B) to observed CPR basalts. Results are consistent with incorporation of up to $2 \%$ sediment during volcanic phase I (Formation A) and from 5 to $8 \%$ in phases III (Perchas $\mathrm{Fm}$ ) and IV; $\mathrm{SiO}_{2}<55 \%$.

increase total degree of melting in arcs relative to MORB environments $(\sim 10 \%)$, to a range between 15 and 30\% (Pearce and Parkinson, 1993). In general, Yb abundances in the northeast Antilles cluster along the $1.0 \mathrm{ppm} \mathrm{Yb}$ level throughout the suite (Figs. 11A to D), corresponding with an average of approximately $25 \%$ melting, but it is noted maximum melting proportions within individual volcanic phases tended to increase in time from 30 to $35 \%$ in volcanic phase I to between 25 and $40 \%$ in phase III. In addition, fields of early Antilles basalts plot slightly below the FM melting curve, indicating slightly depleted source compositions between RMM2 and RMM5.

Chondrite-normalized incompatible element spectra of fractional melts calculated utilizing these parameters ( $f$ $=0.25$ in RMM2), combined with various proportions of AKPS (0.005, 0.1, 0.02, 0.04, 0.06, 0.08, 010), are illustrated in Fig. 12. The patterns reproduce typical features of CPR IAB, including elevated LREE slopes and deep negative HFSE anomalies. Shallow slopes in volcanic phase I are consistent with incorporation of 0.5 to $2 \%$ AKPS, similar to modern arcs (Ellam and Hawkesworth, 1988), including Tonga (Ewart and Hawkesworth, 1987) and the Marianas and New Britain (Woodhead et al., 1998; Fig. 10A). More enriched slopes in phases II and III reflect incorporation of much higher proportions of pelagic sediment, exceeding $>5 \%$ in certain flows from CPRIII.

\section{Covariance of $\mathrm{La} / \mathrm{Nb}-\mathrm{Nb} / \mathrm{Zr}$ in Antilles IAB}

Although multiple component mixing models involving introduction of pelagic sediment into a spinel peridotite source produce normalized incompatible element spectra resembling observed Antilles IAB, including variably enriched REE and deep negative normalized HFSE anomalies (Fig. 12), the models do not exclude presence of an additional enriched mantle component. It is noted however that $\mathrm{La} / \mathrm{Nb}$ is approximately proportional to degree of mantle enrichment at constant sediment content, while conversely $\mathrm{Nb} / \mathrm{Zr}$ is proportional to absolute magnitude of the sediment component. Hence, taken together $\mathrm{La} / \mathrm{Nb}$ and $\mathrm{Nb} / \mathrm{Zr}$ unambiguously discriminate enriched and depleted mantle, island arc basalts, and pelagic sediment.

$\mathrm{La} / \mathrm{Nb}$ and $\mathrm{Nb} / \mathrm{Zr}$ for Mesozoic oceanic basalts from western Puerto Rico, the Caribbean Cretaceous Basalt Plateau, and various modern MORB basalts (Sun and McDonough, 1989), are illustrated in Figs. 13A and 13B. Also included is the mantle trend, consisting of fertile MORB mantle (FM; Pearce and Parkinson, 1993; Bédard, 1999), depleted mantle (RMM1, RMM2, RMM5 representing mantle residue of 1,2 , and $5 \%$ melting in FM), and enriched mantle compositions (primitive mantle and ocean island basalt from Sun and McDonough, 1989). Like IAB from many modern subduction zones (compare Fig. 13A with 13B), Antilles basalts $\left(\mathrm{SiO}_{2}<55 \%\right)$ form a series of fields subparallel to the field of AKPS, intermediate between pelagic sediment and moderately depleted peridotite sources. Fractional crystallization vectors indicate that removal of realistic proportions of plagioclase (pl) and clinopyroxene (cpx) produced small compositional variations. Insead, elongation of individual fields (Figs. 13A to $13 \mathrm{H}$ ) toward high-La/Nb, low $\mathrm{Nb} / \mathrm{Zr}$ is consistent with contamination by small proportions of lowpressure crustal melts, similar to plagiorhyolites from the

FIGURE 13 Covariation of $\mathrm{Nb} / \mathrm{Zr}$ and $\mathrm{La} / \mathrm{Nb}$ in selected arc basalt units $\left(\mathrm{SiO}_{2}<55 \%\right.$ ) from CPR (A) and selected modern IAB (B), including the Aeolian Islands (Ellam et al., 1988), Philippines (McDermott et al., 1993), New Britian (Woodhead et al., 1998), New Hebridies (Dupuy et al., 1982), Papua New Guinea (Kennedy et al., 1990), and S. Sandwich Islands (Cohen and O'Nions, 1982). Symbols within individual fields are indicated by unit codes from Table 1 (see Appendix); field boundaries as in Fig. 14A. For reference, data from the Virgin Island and northeast Puerto Rico are indicated in C-H; for clarity, fields only are shown for the Santa Olaya Fm (SO and S02). All diagrams include mixing lines for $25 \%$ melts of a hypothetical source composed of a mixture of FM, RMM1, RMM2, and RMM5 combined with various proportions (0.5, 1, 2, 4, 6, 8 10\%) of pelagic sediment (average AKPS, Table 2, see Appendix). Atlantic MORB data are from Dosso et al. (1993), WPR MORB field from data are from Jolly et al. (1998b) and unpublished data. Least squares regression lines for these and other units listed in Table 1 (see Appendix) are illustrated in Fig. 14A. 

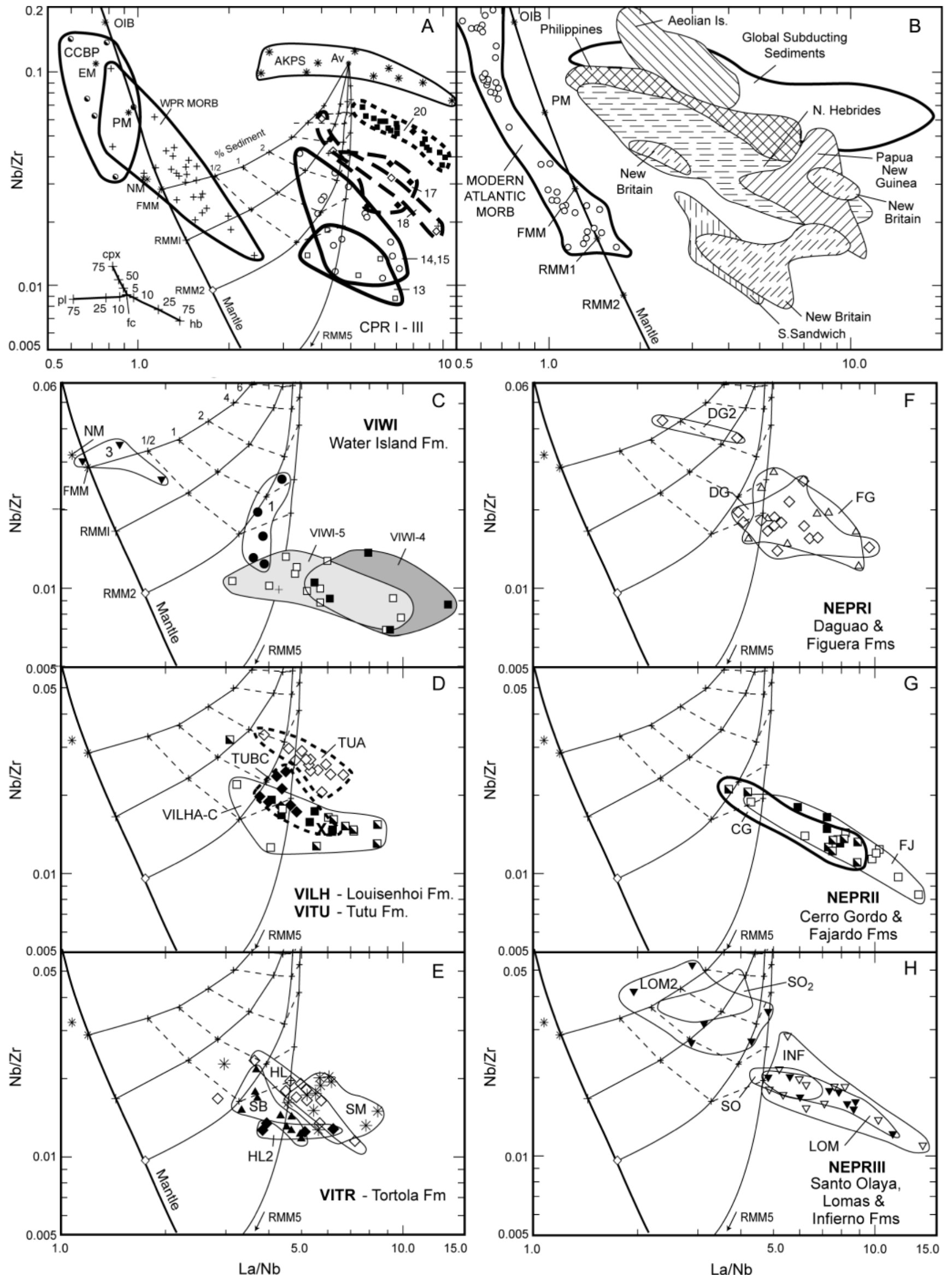
Water Island Fm in the Virgin Islands (Fig. 13C; Jolly and Lidiak, this volume). Accordingly, least-contaminated, low-La/ $\mathrm{Nb}$ basalt end members at left are inferred to most closely reflect plagic sediment proportions.

Antilles basalts form a vertical band with a wide range in $\mathrm{Nb} / \mathrm{Zr}$. In $\mathrm{CPR}$, for example, $\mathrm{Nb} / \mathrm{Zr}$ increases eightfold, from approximately 0.01 to 0.08 , between volcanic phases I (solid lines in Fig. 13B) to III (short dashes),

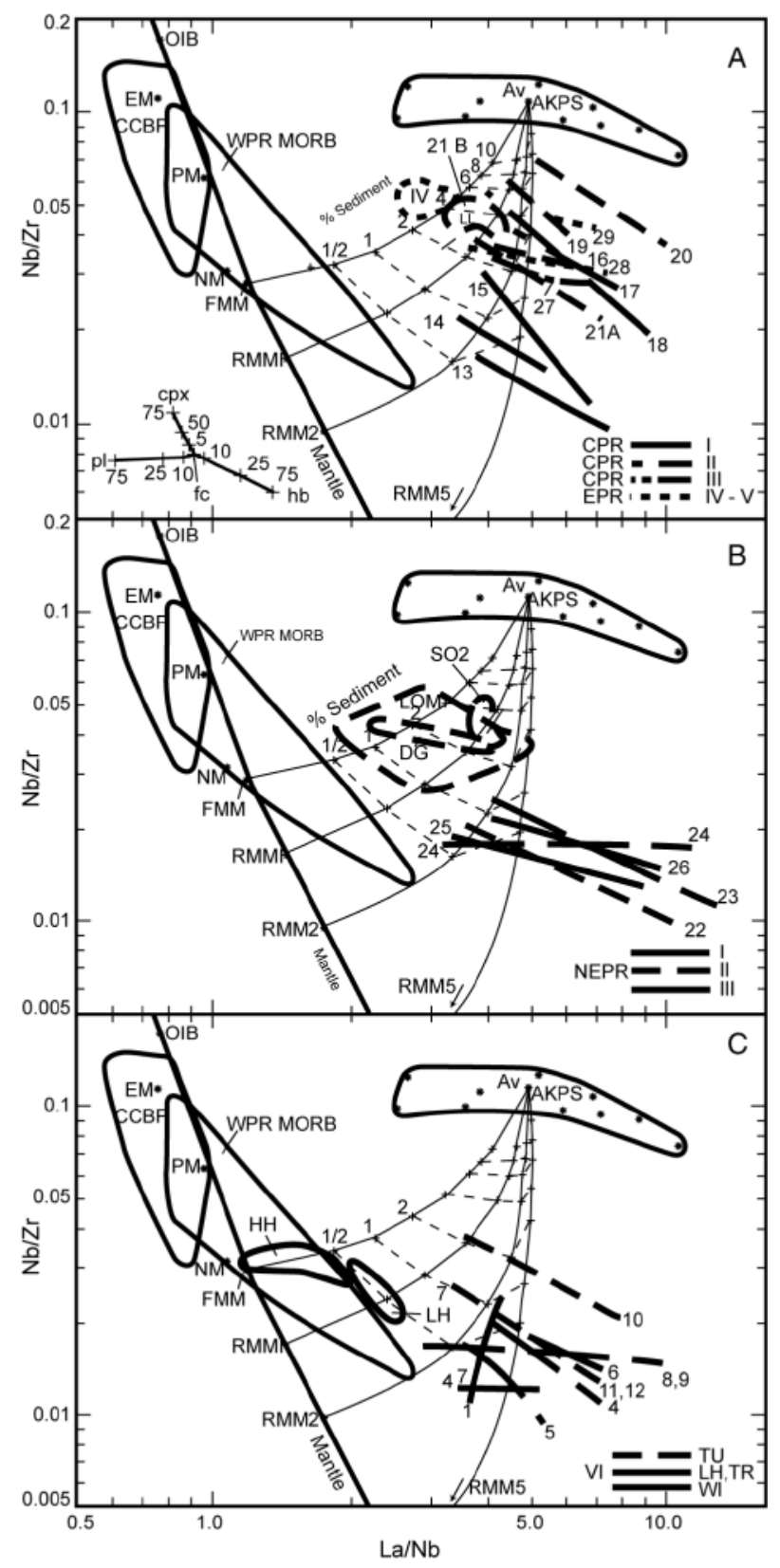

FIGURE 14 1 Covariation of $\mathrm{Nb} / \mathrm{Zr}$ and $\mathrm{La} / \mathrm{Nb}$ in northeastern Antilles IAB as expressed by least squares regressions. Unit codes are from Table 1 (see Appendix). A) Virgin Islands. B) CPR. C) NEPR. Fields of lowLa/Nb basalts (lower-degree melts) are illustrated separately at left; symbols as in Fig. 10. reflecting a voluminous increase in the proportion of sediment. Antilles basalts also have a broad range of $\mathrm{La} / \mathrm{Nb}$, from 3 to over 10, but values are all relatively high compared to FM, consistent with a slightly depleted source. In more general terms, Antilles basalts have consistently high $\mathrm{La} / \mathrm{Nb}$ and relatively low $\mathrm{Nb} / \mathrm{Zr}$, both of which are inconsistent with the presence of a significant OIB-type component. Small numbers of relatively low $\mathrm{La} / \mathrm{Nb}$ basalts, corresponding with high-Yb end-members noted in $\mathrm{Nb}$-Yb diagrams (Figs. 11A to 11D), are present in all three regions of the northeast Antilles (Figs. 14 to $14 \mathrm{H}$ )). Compositions of these anomalous basalts are consistent with relatively low degrees of melting $(<15 \%)$. In comparison the main fields have consistently lower $\mathrm{Yb}$, averaging about 1 ppm, indicating between 15 to $40 \%$ melting.

\section{Lateral and vertical variation in proportions of subducted sediment}

Mixing trends of calculated multiple component melts ( $f=0.25$; see Figs. 11A to $11 \mathrm{D}$ ), derived from mixtures of selected mantle peridotite sources (FM, RMM1, RMM2, RMM5) and a range of sediment proportions (0, 1, 2, 4, 6, 8 10\%), are superimposed on $\mathrm{La} / \mathrm{Nb}-\mathrm{Nb} / \mathrm{Zr}$ plots in Figs. 13 and 14. Mixing trajectories involving FM and more depleted residual mantle compositions (RMM1) form sweeping, hyperbolic curves extending diagonally between the mantle trend line and pelagic sediments, while trends for more depleted sources ( $>$ RMM2) are almost vertical with relatively constant $\mathrm{La} / \mathrm{Nb}$. Consequently, relative magnitudes of the sediment component are proportional to $\mathrm{Nb} / \mathrm{Zr}$ at the intersection between the field of a given basalt unit and the appropriate vertical mixing line (approximately RMM2, Fig. 11A; see also Jolly and Lidiak, this volume). To facilitate comparisons across the Antilles (Table 1, see Appendix), estimates of sediment proportions were standardized by measurement of intersections between 1) least-squares regression lines for each unit and 2) the RMM2 mixing trajectory in Fig. 14.

Results reveal that sediment proportions in the Virgin Islands range from an average of between 0.3 and $0.7 \%$ in more typical basalts from the Water Is., Louisenhoj, and Tortola Fms, and about $2 \%$ in the Tutu Fm. The narrow range is consistent with subductioin of a sediment-poor, extinct ridge-related tectonic setting (Fig. 15A). In comparison, estimated sediment proportions in NEPR are similarly low, ranging from less than $0.5 \%$ to a maximum of about $2 \%$ sediment. In $\mathrm{CPR} \mathrm{Nb} / \mathrm{Zr}$ indicates a radically different sequence involving gradually but spectacularly increasing sediment proportions, ranging from $<1.5 \%$ in early Albian basalts ( 112 to $100 \mathrm{Ma}$ ) to between 5 and $8 \%$ in Cenomanian (100 to $94 \mathrm{Ma}$ ) end-members (Fig. 15A). The compositional shift in CPR from a) low-sediment basalts resembling Cenozoic intra-oceanic arc basalts (New Britain, northern 
Antilles, Aleutians; Fig. 2), to b) sediment-rich types, resembling continental margin arcs (Grenada, Philippines, Aeolian Is.), is consistent with change from an open oceanic- to a continental-margin tectonic setting.

\section{PELAGIC SEDIMENT BUDGET IN THE NORTHEAST ANTILLES}

\section{Tectonic evolution of the modern Caribbean basin}

Plate rotation models of Caribbean tectonics (Pindell et al., 1988; Donnelly, 1989) begin with opening of the
Atlantic basin during Jurassic time, which in the southwestern Caribbean region involved spreading between the North and South American Plates (Fig. 16). This process produced a narrow southwest-trending oceanic basin with a centrally located mid-oceanic ridge system extending longitudinally between the two continents. Since spreading involved a southwestern extension of the early midAtlantic ridge system, this basin is here identified for convenience and clarity as the proto-Atlantic basin rather than proto-Caribbean in the terminology of Pindell and Barrett (1990). Most tectonic models (Burke, 1988; Pindell and Barrett, 1990; Lebron and Perfit, 1994; Draper et al., 1996; Lewis et al., 2002), developed primarily in His-

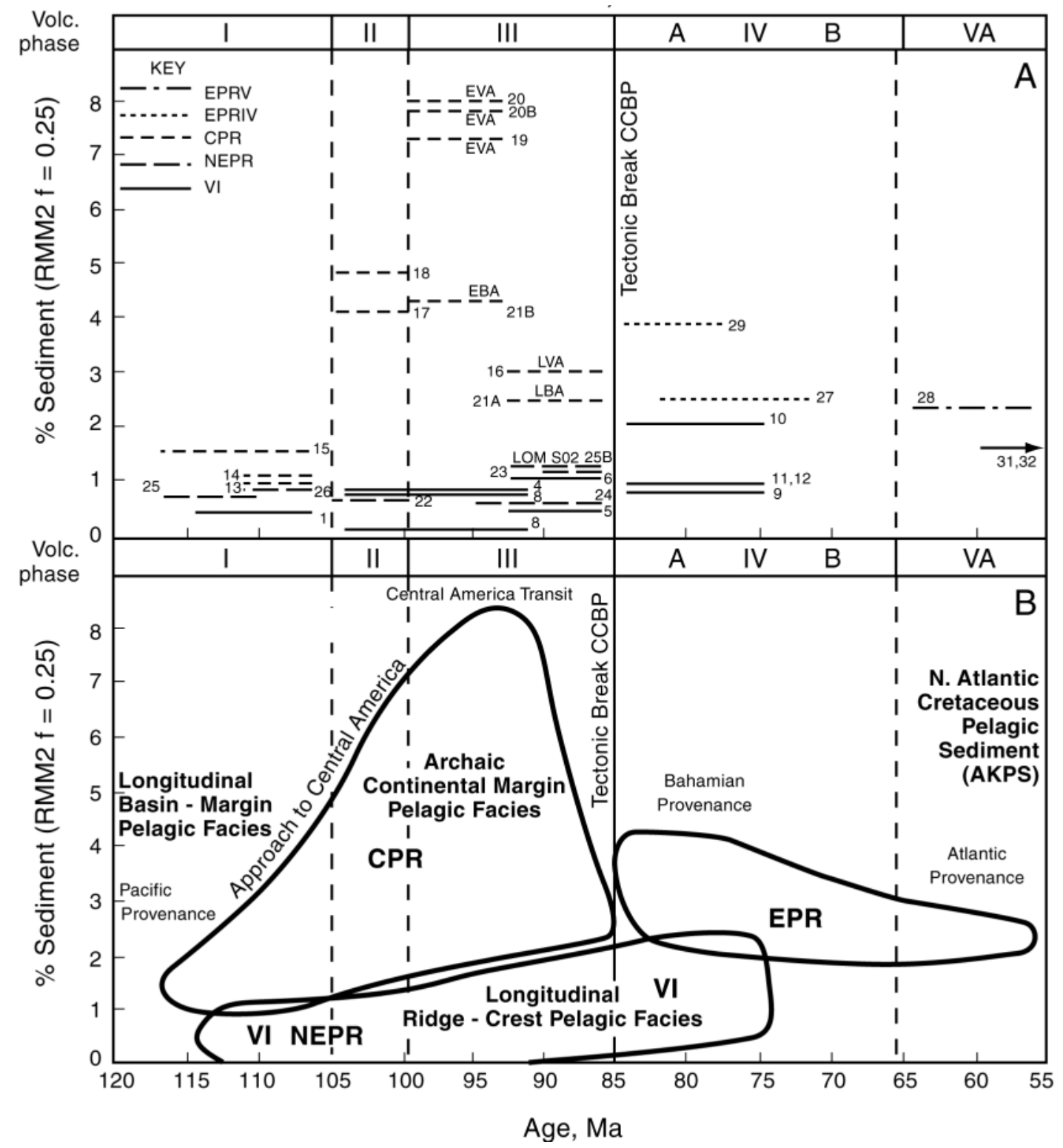

FIGURE 15 | Pelagic sediment budget in the northeastern Antilles according to age and estimated pelagic sediment components of basalts (SiO ${ }_{2}<$ 55\%) from Puerto Rico (CPR and NEPR) and the Virgin Islands (VI). A) Unit codes are from Table 1 (see Appendix). EVA: early phase III volcanic axis; EBA: early back arc strata; LVA: late volcanic phase III volcanic axis; LBA: late back arc strata; LOM: Lomas Fm; S02: Santa Olaya subunit 2. B) Fields representing sediment facies (from Fig. 16B) and ranges of sediment proportions in Virgin Islands (VI) and Northeastern, Central and Eastern Puerto Rico (NEPR, CPR and EPR respectively). 
paniola, consist of three distinct stages, including 1) early establishment of a northeast-dipping subduction zone and associated island arc chain linking the western margins of North and South America and effectively closing the gap between the Pacific and proto-Atlantic basins during Aptian or Early Albian time ( 125 Ma), 2) collision of
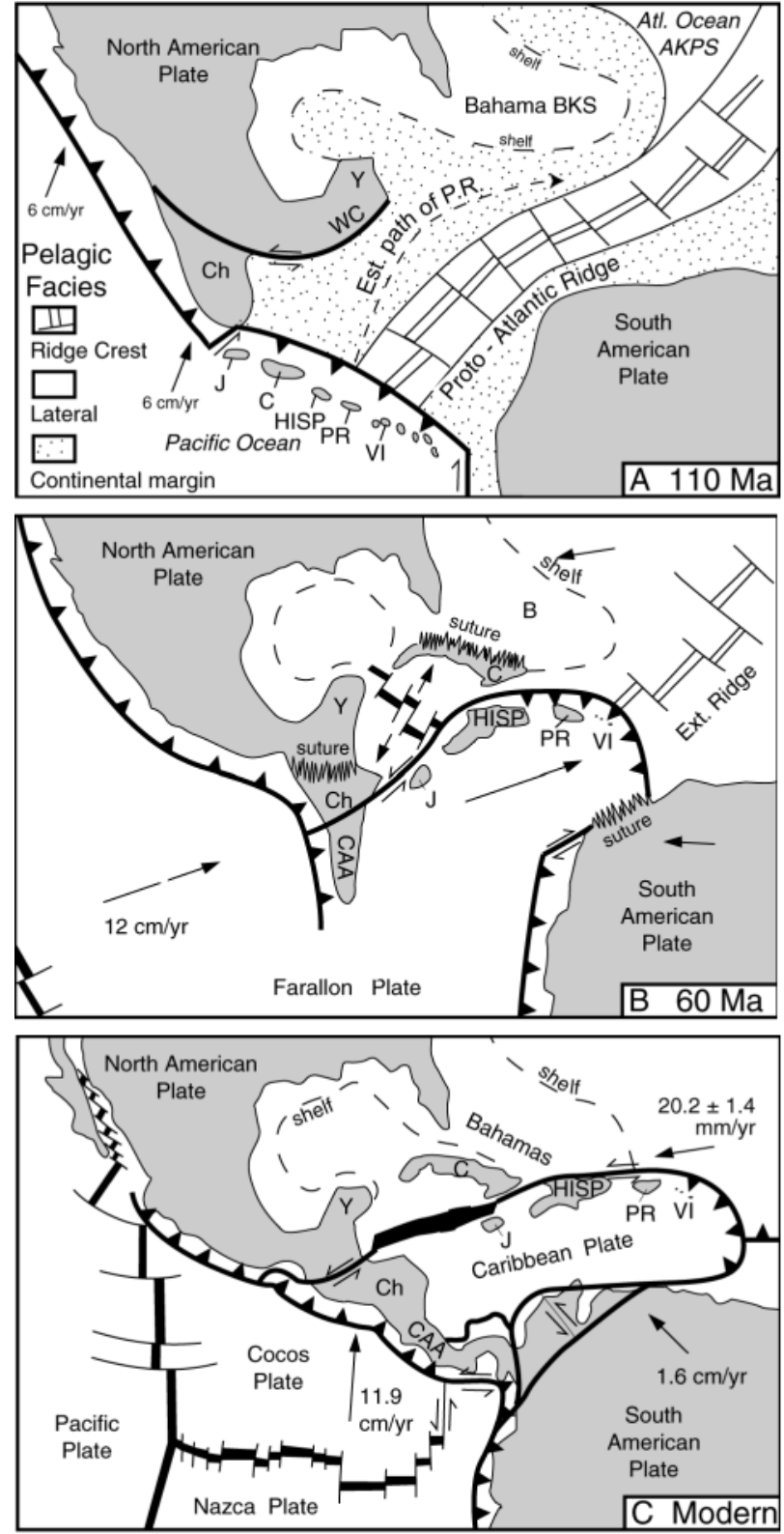

the juvenile northeast-dipping arc system with an eastward drifting oceanic plateau, the Duarte Terrane of central Hispaniola, which was obducted northward onto the arc during Aptian to mid Albian time, and 3) a reversal in polarity of subduction from northeast- to southwest-dipping and generation of a second, subparallel arc system beginning in Late Albian time. A variant of this model was proposed by Lapierre et al. (1997, 1999; see also discussion in Lewis et al., 1999), who suggested collision between the Duarte block and the Antilles arc occurred later, during Santonian time $(<85 \mathrm{Ma})$, in association with development of the Caribbean Cretaceous Basalt Plateau. South-dipping subduction polarity during the entire interval from Albian to Santonian time is implicit in all these models.

Despite uncertainty regarding tectonism accompanying early subduction in the Antilles, there is consensus that, following establishment of the south-dipping Antilles subduction zone, the Pacific Plate was inserted into the protoAtlantic basin by north-northeast convergence (Figs. 16A to 16C). Accordingly, pelagic sediment subducted by the Puerto Rico - Virgin Islands (PRVI) sector of the arc shifted from a low-sediment, ridge-related to a continental margin facies, composed of sediments associated with the pre-drift North and South American continents. Subsequently, a shift from northeast to east-northeast convergence deflected motion of the northeast Antilles toward the Bahama Banks, and during Maastrichtian to Eocene time, Hispaniola collided with the southeast margin of the North American Plate in the Bahama Banks region (Pindell and Barrett, 1990). PRVI, which skirted the southern fringes of the Bahamas, escaped a similar fate and was swept instead past the continental margin toward the open Atlantic Ocean (Donnelly, 1989). Since Maastrichtian time motion of the Caribbean Plate has been largely restricted to left-lateral strike-slip displacement along the Puerto Rico Trench Thrust (Fig. 16D; Pindell and Barrett, 1990; Pindell, 1994).

\section{Distribution of pre-arc sedimentary facies in the proto-Atlantic basin}

Variation in magnitude of the Late Cretaceous pelagic sediment component in the northeast Antilles is characterized by consistently low values in VI and NEPR on the

FIGURE 16 | Pre-arc pelagic sediment facies in the proto-Atlantic (=proto-Caribbean of Pindell and Barrett, 1990) region and tectonic evolution of the Antilles island arc (modified from Donnelly, 1989; Pindell and Barrett, 1990; Kerr et al., 1999; Lapierre et al., 1997, 1999). WC: Western North America - Chortis boundary zone; Ch: Chortis block; B: Bahama Banks; Y: Yucatan; CAA: Central America Arc; J: Jamaica; Hisp: Hispaniola; C: Cuba; vectors from Pindell et al. (1988). A) The early stages of subduction along the southwest margin of the proto-Atlantic basin in early Cretaceous time (125 Ma). Convergence from this period through Santonian time ( $85 \mathrm{Ma}$ ) was primarily northeast-directed. The Chortis block has separated from Mexico. A north easterly-dipping subduction zone, possibly related to eruption of bonninitic Maimon basalts (Horan, 1995; Lewis et al., 2000), fringes the west-drifting North America Plate. Hypothetical distribution of pelagic sediment facies in the proto-Atlantic basin prior to southwest-dipping subduction and development of the Antilles arc, based on pelagic sediment budget in the northeast Antilles (Fig. 15), is indicated. B) Final stages of insertion of the Caribbean Plate into the gap between North and South America ( $65 \mathrm{Ma}$ ). The estimated path of Puerto Rico across the basin (dashed line with arrow reflecting the convergence vector) indicates CPR and Hispaniola subducted continental margin pelagic sediments, partly inherited from pre-spreading sources, whereas the Virgin Islands (and NEPR) subducted material from the extinct proto-Atlantic ridge crest. C) Modern Caribbean region with modern plate motion vectors for North and South America and the Cocos Plate, relative to the Caribbean Plate (Pindell et al., 1988). 
east, and a gradual shift from moderately low to exceedingly high values in CPR on the west. This pattern mirrors sediment distribution expected along a transverse, from ridge to basin margin, across a relatively young and narrow oceanic basin such as the proto-Atlantic during Cretaceous time. Pre-arc pelagic sediment facies within this hypothetical basin (Fig. 16B) were dominated by a young, centrally located, longitudinal ridge-crest pelagic facies, and flanking, subparallel belts of slightly older and thicker basin-margin pelagic facies. A continental margin pelagic facies, of variable thickness, inherited from prespreading sedimentary basins associated with continental break-up, comprised margins of the basin.

As the developing arc advanced northeastward across the Caribbean, motion of VI followed the northeast trace of the proto-Atlantic ridge-crest. Consequently, proportions of subducted sediment in VI basalts remained low from early Albian time until the mid-Santonian. The marginal position of CPR in the arc with respect to VI and NEPR brought that segment into close proximity with the northwestern margin of the basin. Consequently, CPR basalts incorporated increasing proportions of continental sediment as the system approached Central America and the Yucatan during Cenomanian time. The unusually high apparent sediment content in CPRIII basalts (up to $8 \%$ ) possibly reflects subduction of a high- $\mathrm{Nb} / \mathrm{Zr}$ component inherited from continental detritus. In neighboring Hispaniola, relatively enriched radiogenic $\mathrm{Pb}$ ratios in the Los Ranchos Fm (Albian, $110 \mathrm{Ma}$, Kesler and Crawford, in press) indicate the sediment content of Hispaniola basalts was high not only during Cenomanian phases of the arc, but also during earlier Albian time, reflecting consistent subduction of a large component of continental margin pelagic sediments throughout arc history (Joyce, 1990). Hispaniola ultimately collided with the Bahamas during the Maastrichtian -Eocene interval (Pindell, 1994), whereas Puerto Rico and the Virgin Islands were diverted east of the Bahamas toward the North Atlantic Basin. At that time sediment proportions stabilized between 2 to $3 \%$ until extinction of the arc in the mid-Eocene.

\section{CONCLUSIONS}

Incompatible element abundances in basalts from the northeast Antilles reflect wide variation in sediment proportions along a $450 \mathrm{~km}$ section of the island arc from the Virgin Is (VI) to Puerto Rico (CPR and NEPR). LowLREE/HREE, PIA-type basalts with limited sediment content $(<1.0 \%)$ predominate in Albian to Cenomanian strata from VI and NEPR. Similar basalts, with slightly higher LREE/HREE, are also present in early Albian stra- ta from CPR, but high-LREE/HREE calcalkaline varieties, with elevated sediment proportions (between 4 and $8 \%$ ) predominate in CPR Cenomanian strata. Covariation of $\mathrm{La} / \mathrm{Nb}$ and $\mathrm{Nb} / \mathrm{Zr}$ in Antilles basalts indicate the differences result from south-dipping subduction of several distinct pre-arc pelagic sediment facies associated with the proto-Atlantic ridge system that separated North and South America during the Late Cretaceous. Basalt compositions in VI and NEPR are consistent with subduction of a sediment-depleted longitudinal ridge-crest pelagic sediment facies occupying the central part of the basin. Similar basalts in Albian strata from CPR have slightly higher sediment proportions, consistent with subduction of a lateral basin-margin pelagic facies. During Cenomanian time, the approach of the arc system to Central America and the Yucatan along the southwest fringes of the North American Plate was accompanied in CPR basalts by a massive increase in sediment proportions, reflecting incorporation of archaic, pre-spreading continental margin pelagic sediments, probably similar to pelitic strata preserved in the blueschist terrains of the Samana Peninsula, northern Hispaniola. Thereafter, sediment proportions in northeast Antilles island arc basalts declined progressively, reflecting entry of the arc into the open Atlantic Ocean.

\section{ACKNOWLEDGEMENTS}

This paper is a contribution to IGCP Project 433. The authors are grateful to T. W. Donnelly, who selected and provided DSDP core samples of Atlantic pelagic sediment (AKPS) for this project. Helpful reviews of the manuscript by Manuel A. Iturralde-Vinent, John J. W. Rogers and J. H. Schellekens, and discussions with J. Joyce regarding Caribbean tectonics and pelites in the Samana Peninsula of Hispaniola, are gratefully acknowledged. Graphics were prepared by Mike Lozon of the Department of Earth Sciences at Brock University. Financial assistance for this project is provided by the National Science and Engineering Research Council of Canada (NSERC), and by travel funds from IGC Project 433 on Tectonics of the Caribbean Plate Boundary.

\section{REFERENCES}

Arculus, R.J., Powell, R., 1986. Source component mixing in the regions of arc magma generation. Journal of Geophysical Research, 91 (B6), 5913-5926.

Bawiec, W.J., 2001. Geology, Geochemistry, Geophysics, Mineral Occurrences, and Mineral Resource Assessment for the Commonwealth of Puerto Rico (ed.). U. S. Geological. Survey, Open File Report CD-ROM, 98-38.

Bédard, J.H., 1999. Petrogenesis of boninites from the Betts Cove Ophiolite, Newfoundland, Canada: Identification of 
subducted source components. Journal of Petrology, 40, 1853-1889.

Ben-Othman, D., White, W.M., Patchett, J., 1989. The geochemistry of marine sediments, island arc magma genesis, and crust-mantle recycling. Earth and Planetary Science Letters, 94, 1-21.

Berryhill, H.L., Jr., Briggs, R.P., Glover, L., Jr., 1960. Stratigraphy, sedimentation and structure of Late Cretaceous rocks in eastern Puerto Rico-preliminary report. American Association of Petroleum Geologists Bulletin, 44, 137-155.

Boynton, C.H., Westbrook, G.K., Bott, M.H.P., 1979. A seismic refraction investigation of crustal structure beneath Lesser Antilles island arc. Geophysical Journal, Royal Astronomical Society, 58, 371-393.

Briggs, R.P., 1973. The Lower Cretaceous Figuera Lava and Fajardo Fm in the stratigraphy of northeastern Puerto Rico. United States Geological Survey Bulletin, 1372-G, 10 pp.

Burke, K., 1988. Tectonic evolution of the Caribbean. Annual Reviews of Earth and Planetary Sciences, 16, 201-30.

Cohen, R.S., O'Nions, R.K., 1982. Identification of recycled continental material in the mantle from $\mathrm{Sr}, \mathrm{Nd}$, and $\mathrm{Pb}$ isotope investigations. Earth and Planetary Science Letters, 61, 73-84.

Cox, D.P., Marvin, R.F., McGonigle, J.W., McIntyre, D.H., Rogers, C. I., 1977, Potassium-argon geochemistry of some metamorphic, igneous, and hydrothermal events in Puerto Rico and the virgin Islands. U. S. Geological Survey Journal of Research, 5, 689-703.

Cumming, G.L., Kesler, S.E., 1987. Lead isotopic composition of the older volcanic rocks of the eastern Greater Antilles arc. Chemical Geology, 65, 15-23.

Davidson, J.P., 1986. Isotopic and trace element constraints on the petrogenesis of subduction-related lavas from Martinique, Lesser Antilles. Journal of Geophysical Research, 91(B), 5943-5962.

Davidson, J.P., 1987. Crustal composition vs. subduction zones enrichment: examples from the Lesser Antilles and implications for mantle source compositions of island arc volcanic rocks. Geochimica Cosmochimica Acta, 51, 2185-2198.

Davies, J.H., Stevenson, D.J., 1992. Physical model of source region of subduction zone volcanics. Journal of Geophysical Research, 97, 2037-70.

Donnelly, T.W., 1966. Geology of St. Thomas and St. John, U.S.Virgin Island. In: Hess, H.H. (ed.). Caribbean Geological Investigations. Boulder, Colorado, Geological Society of America Memoir, 98, 5-176.

Donnelly, T.W., 1978. Chemistry of sediments of the western Atlantic: site 417 compared with sites 9, 105, 386, 387. Initial Reports of the Deep Sea Drilling Project, 51B53, 1515-1523.

Donnelly, T.W., 1989. Geologic history of the Caribbean and Central America. In: Bally, A.W., Palmer, A.R. (eds.). Geology of North America-An Overview. Boulder, Colorado, Geological Society of America Special Paper A, 299-321.

Donnelly, T.W., Rogers, J.J.W., Pushkar, P., Armstrong, R.L., 1971. Chemical evolution of the igneous rocks of the eastern West Indies: An investigation of thorium, uranium, and potassium distribution and lead and strontium isotopic ratios. In: Donnelly, T.W. (ed.) Caribbean geophysical, tectonic, and petrologic investigations. Boulder, Colorado, Geological Society of America Memoir 130, 181-224.

Donnelly, T.W., Thompson, G., Salisbury, H., 1978. The chemistry of altered basalts at site 417, Leg 51. Initial Reports of the Deep Sea Drilling Project, 51-53, 1319-1330.

Donnelly, T.W., Rogers, J.J.W., 1980. Igneous series in island arcs. Bulletin of Volcanlogy, 43, 347-382.

Donnelly, T.W., Beets, D., Carr, M.J., Jackson, T., Klver, G., Lewis, J.F., Maury, R., Schellekens, H., Smith, A.L., Westercamp, D., 1990. History and tectonic setting of Caribbean magmatism. In: Case, J.E., Dengo, G. (eds.). Caribbean Region. Boulder, Colorado, Geological Society of America, $\mathrm{H}$, 339-374.

Dosso, L., Bougault, H., Joron, J.-L., 1993. Geochemical morphology of the North Mid-Atlantic Ridge, 10-24: Trace element-isotope complementarity. Earth and Planetary Science Letters, 120, 443-462.

Draper, G., Guitierrez, G., Lewis, J.F., 1996. Thrust emplacement of the Hispaniola peridotite belt: orogenic expression of the mid-Cretaceous Caribbean arc polarity reversal. Geology, 24, 1143-1146.

Dupuy, C., Dostol, J., Marcelot, G., Bougault, H., Joron, J.L., Treuil, M., 1982. Geochemistry of basalts from southern New Hebrides arc: implications for their source rock compositions. Earth Planetary Science Letters, 60, 207-225.

Ellam, R.M., Hawkesworth, C.J., 1988. Elemental and isotopic variations in subduction-related basalts: evidence for a three component model. Contributions to Mineralogy and Petrology, 98, 72-80.

Ellam, R.M., Menzies, M A., Hawkesworth, C.J., Leeman, W.P., Rosi, M., Serri, G., 1988. The transition from calc-alkaline to potassic orogenic magmatism in the Aeolian Islands, Southern Italy. Bulletin Volcanology, 50, 386-98.

Elliot, T., Plank, T., Zindler, A., White, W.M., Bourdon, B., 1997. Element transport from the slab to volcanic front at the Mariana arc. Journal of Geophysical Research, 102, 14991-15019.

Ewart, A.W., Hawkesworth, C.J., 1987. Pleistocene to recent Tonga-Kermadec are lavas: interpretation of new isotope and rare earth data in terms of a depleted mantle source model. Journal of Petrology, 28, 495-530.

Frost, C.D., Schellekens, J.H., 1991. Rb-Sr and Sm-Nd isotopic characterization of Eocene volcanic rocks from Puerto Rico. Geophysical Research Letters, 18, 545-548.

Frost, C.D., Schellekens, J.H., Smith, A., 1998. Nd, Sr, and Pb isotopic characterization of volcanic and plutonic igneous rocks from Puerto Rico. In: Lidiak, E.G., Larue, D.K. (eds.).Tectonics and Geochemistry of the Northeastern Caribbean, Geological Society of America Special Paper, 322, 123-132, 1998.

Glover, L., III, 1971. Geology of the Coamo area, Puerto Rico, 
and its relation to the volcanic arc-trench association. U.S. Geological Survey Professional Paper 636, 102 pp.

Hauff, F., Hoernle, K., Tilton, G., Graham, D.W., Kerr, A.C., 2000. Large volume recycling of oceanic lithosphere over short time scales: geochemical constraints from the Caribbean Large Igneous Province. Earth and Planetary Science Letters, 174, 247-263.

Hauff, F., Hornle, K., Schmincke, H.U., Werner, R., 1997. A mid-Cretaceous origin for the Galapagos Hotspot: Volcanological, pertrological, and geochemical evidence from Costa Rican oceanic crustal segments. Geologisch Rundschou, 86, 141-155.

Hart, S.R., 1984. A large-scale isotope anomaly in the southern hemisphere mantle. Nature, 309, 753-57.

Hawkesworth, C.J., Gallagher, K., Hergt, J.M., McDermott, F., 1993. Mantle and slab contributions in arc magmas. Annual Reviews of Earth and Planetary Sciences, 21, 175-204.

Hawkesworth, C.J., Powell, M., 1980. Magma genesis in the Lesser Antilles island arc. Earth and Planetary Science Letters, 51, 297-308.

Hekinian, R., 1971. Petrological and geochemical studies of spilites and associated rocks from St. John, U.S. Virgin Islands. Geological Society of America Bulletin, 82, 659-682.

Helsley, C.E., 1960. Geology of the British Virgin Islands. Doctoral thesis. Princeton University, NJ, 167 pp.

Hole, M.J., Saunders, A.D., Marriner, G.F., Tarney, J., 1984. Subduction of pelagic sediments: implications for the origin of Ce-anomalous basalts from the Mariana islands. Journal of the geological society of London, 141, 453-472.

Horan, S.L., 1995. The geochemistry and tectonic significance of the Maimon-Amina Schists, Cordillera Central, Dominican Republic. M.Sc. thesis. University of Florida, Gainsville, FL, 172 pp.

Iturralde-Vinent, M.A., McPhee, R.D.E., 1999. Paleogeography of the Caribbean region. Implications for Cenozoic biostratigraphy. American Museum of Natural History Bulletin, 238, 1-95.

Jahn, B., Bernard-Griffiths, J., Charlot, R., Cornichet, J., Vidal, F., 1980. Nd and $\mathrm{Sr}$ isotopic compositions and REE abundances of Cretaceous MORB (Holes 417D and 418A, Legs 51, 52, and 53). Earth and Planetary Science Letters, 48, 171-84.

Jansma, P., Mattioli, G., Lopez, A., DeMets, C., Dixon, T. H., Mann, P., Calais, E., 2000. Neotectonics of Puerto Rico and the Virgin Islands, northeastern Caribbean, from GPS geodesy. Tectonics, 19, 1021-1037.

Johnson, K.M.T., Dick, H.J.B., 1992. Open-system melting and temporal and spatial variation of peridotite and basalt at the Atlantic fracture zone. Journal of Geophysical Research, 97, 9219-9241.

Jolly, W.T., Lidiak, E.G., Schelleckens, H.S., Santos, S., 1998a. Volcanism, tectonics, and stratigraphic correlations in Puerto Rico. In: Lidiak, E.G., Larue, D.K. (eds.). Tectonics and Geochemistry of the Northeast Caribbean. Boulder, Colorado, Geological Society of America, Special Paper, 322, 1-34.
Jolly, W.T., Lidiak, E.G., Dickin, A.P., Wu, T.S., 1998b. Geochemical diversity of Mesozoic island arc tectonic blocks, eastern Puerto Rico. In: Lidiak, E.G., Larue, D.K. (eds.). Tectonics and Geochemistry of the Northeastern Caribbean. Boulder, Colorado, Geological Society of America Special Paper, 322, 67-89.

Jolly, W.T., Lidiak, E.G., Dickin, A.P., Wu, T.W., 2001. Secular geochemistry of central Puerto Rican island arc lavas: constraints on Mesozoic tectonism in the Greater Antilles. Journal of Petrology, 42, 2197-2214.

Jolly, W.T., Lidiak, E.G., Dickin, A.P., Wu, T.S., 2002. Recycling in the Puerto Rican mantle wedge, Greater Antilles island arc. The Island Arc, 11, 10-24.

Jolly, W.T., Lidiak, E.G., 2006. Role of crustal melting in petrogenesis of the Cretaceous Water Island Formation (Virgin Islands, northeast Antilles Island arc). Geologica Acta, 4, 7-33.

Joyce, J., 1990. Blueschist metamorphism and deformation on the Samana Peninsula: a record of subduction and collision in the Greater Antilles. Geological Society of America Special Paper, 262, 47-76.

Kaczor, L., Rogers, J.J.W., 1990. The Cretaceous Aguas Buenas and Río Matón Limestones of southern Puerto Rico. Journal of South America Earth Science, 3, 1-8.

Kennedy, A.W., Hart, S.R., Frey, F.A., 1990. Compositions and isotope constraints on the petrogenesis of alkaline arc lavas: Lihir Islands, Papua New Guinea. Journal of Geophysical Research, 95, 6929-6942.

Kerr, A.C., Iturralde-Vinent, M.A., Saunders, A.D., Babbs, T.L., Tarney, J., 1999. A new plate tectonic model of the Caribbean: Implications from a geochemical reconnaisance of Cuben Mesozoic volcanic rocks. Geological Society of America Bulletin, 55, 1581-1599.

Kerr, A.C., Tarney, J., Kempton, P.D., Spaden, S., Nivia, A., Marriner, G. F., Duncan, R.A., 2002. Pervasive mantle plume head heterogeniety: Evidence from the late Cretaceous Caribbean-Columbina oceanic plateau. Journal of Geophysical Research, 107, 1029-2001.

Kesler, S.E., Campbell, I.H., 2005. Age of the Los Ranchos Formation. Dominican Republic, Central Greater Antilles. Geological Society of America Bulletin, 61, 668-682.

Lapierre, H., Dupui, V., Lepinay, B.M., Tardy, M., Ruiz, J., Maury, R.C., Hernandez, J., Loubert, M., 1997. Is the Lower Duarte Complex (Hispañiola) a remnant of the Caribbean plume generated oceanic plateau? Journal of Geology, 105, 111-120.

Lapierre, H., Dupuis, V., Lepinay, B.M., Bosch, D., Moni, P., Tardy, M., Maury, R. C., 1999. Late Jurassic oceanic crust and Upper Cretaceous Caribbean Plateau picritic basalts exposed in the Duarte igneous complex, Hispañiola. Journal of Geology, 107, 193-207.

Larue, D.K., Ryan, H., 1998. Seismic reflection profiles of Puerto Rican Trench: Shortening between the North American and Caribbean plates. In: Lidiak, E.G., Larue D.K. (eds.). Tectonics and Geochemistry of the Northeastern Caribbean. Boulder Colorado, Geological Society of America Special Paper, 332, 193-210. 
Lebron, M.C., Perfit, M.R., 1994. Petrochemistry and tectonic significance of Cretaceous island arc rocks, Cordillera Oriental, Dominican Republic. Tectonophysics, 229, 60-100.

Lewis, J.F., Hames, W.E., Draper, G., 1999. Late Jurassic oceanic crust and Upper Cretaceous Caribban plateau picritic basalts exposed in the Duarte igneous complex, Hispaniola: a discussion. Journal of Geology, 107, 505-508.

Lewis, J.F., Escuder Viruete, J., Hernaiz Huerta, P.P., Gutiérrez, G., Draper, G., Pérez-Estaún, A., 2002. Subdivisión geoquímica del Arco Isla Circum-Caribeño, Cordillera Central Dominicana: Implicaciones para la formación, acreción y crecimiento cortical en un ambiente intraoceánico. Acta Geologica Hispanica, 37, 81-122.

Lidiak, E.G., Jolly, W.T., 1996. Circum-Caribbean granitoids: Characteristics and origin. International Geology Review, 38, 1098-1133.

Mattson, P.H., 1960. Geology of the Mayagüez area, Puerto Rico. Geological Society of America Bulletin, 71, 319-362.

Mattson, P.H., 1979. Subduction, buoyant braking, flipping, and strike-slip faulting in the northern Caribbean. Journal of Geology, 87 293-304.

McDermott, F., Defant, M.J., Hawkesworth, C.J., Maury, R.C., Joron, J.I., 1993. Isotope and trace evidence for three component mixing in the genesis of the North Luzon arc lavas (Philippines). Contributions to Mineralogy and Petrology, 113, 9-33.

McPhee, R.D.E., Iturralde-Vinent, M.A., 1995. Origin of the Greater Antilles land mammal fauna. 1. New Tertiary fossils from Cuba and Puerto Rico. American Museum Novitates, 3141, 31 pp.

McPhee, R.D.E., Iturralde-Vinent, M.A., Gaffney, E., 2003. Domo de Zaza, an early Miocene vertebrate locality in south-central Cuba, with notes on the tectonic evolution of Puerto Rico and Mona Passage. American Museum Novitates, 3394, 42 pp.

McKenzie, D., O’Nions, R.K., 1991. Partial melt distributions from inversion of rare earth element concentrations. Journal of Petrology, 32, 1021-91.

Montgomery, H., Pessagno, E.A., Jr, Lewis, J.F., Schellekens, J.H., 1994. Paleogeography of Jurassic fragments in the Caribbean. Tectonics, 13, 725-732.

Montgomery, H., 1998. Paleogene stratigraphy and sedimentology of the north coast, Puerto Rico. In: Lidiak, E.G., Larue, D.K. (eds.).Tectonics and Geochemistry of the Northeastern Caribbean. Boulder, Colorado, Geological Society of America Special Paper, 322, 177-192.

Myczynski, R., Iturralde-Vinent, M., 2005. The Late Lower Albian invertebrate fauna of the Hatillo Formation of Pueblo Viejo, Dominican Republic. Caribbean Journal of Science, 41, 782-796.

Nicholls, G.T., Wylie, P.J., Stern, C.R., 1994. Subduction zone melting of pelagic sediments constrained by melting experiments. Nature, 371, 785-788.

Peate, D.W., Pearce, J.A., Hawkesworth, C.J., Colley, H., Edwards, C.M.H., Hirose, K., 1997. Geochemical variation in Vanuatu Arc lavas: the role of subducted material and a variable mantle wedge composition. Journal of Petrology, 38, 1331-1358.

Pearce, J.A., Parkinson, I.J., 1993. Trace element models for mantle melting: application to volcanic arc petrogenesis. Geological Society of London Special Paper, 76, 373-403.

Pease, M.H., Jr., 1968. Cretaceous and lower Tertiary stratigraphy of the Naranjito and Aguas Buenas quadrangles. United States Geological Survey Bulletin, 1253, 57 pp.

Pindell, J.L, 1994. Evolution of the Gulf of Mexico and the Caribbean. In: Donovan, S.K., Jackson, T.A., (eds.). Caribbean Geology: An Introduction. Kingston, Jamaica, University of the West Indies Press, 13-39.

Pindell, J.L., Cande, S.C., Pitman, W.C., III, Rowley, D.B., Dewey, J.F., La Barque, J., Haxby, W.,1988. A plate-kinematic framework for models of Caribbean evolution. Tectonophysics, 155, 121-138.

Pindell, J.L.,Barrett, S.F., 1990. Geological evolution of the Caribbean region: a plate tectonic perspective, In: Dengo, G., Case, J.E. (eds.). The Caribbean Region. Boulder, Colorado. Geological Society of America Special Paper H, 405-432.

Plank, T., Langmuir, C.H., 1997. The chemical composition of subducting sediment and its consequences for the crust and mantle. Chemical Geology, 145, 325-394.

Rankin, D., 2002. Geology of St. John, U.S. Virgin Islands. USGS Professional Paper, 1631, 1-36.

Romick, J.D., Perfit, M.R., Swanson, S.E., Shuster, R.D., 1990. Magmatism in the eastern Aleutian Arc: temporal characteristic of igneous activity on Akutan Island. Contributions to Mineralogy and Petrology, 104, 700-721.

Schiano. P., Cloccjiatti, R., Shimizu, N., Maury, R.C., Jochum, K.P., Hoff, A.W., 1995. Hydrous silica-rich melts in the subarc mantle and their relationship with erupted arc lavas. Nature, 377, 594-600.

Schellekens, J.H., Montgomery, H., Joyce, J., Smith, A.L., 1990. Late Jurassic to Late Cretaceous development of island arc crust in southwestern Puerto Rico. University of Miami. Gainsville, Florida. Transactions of the 12th Caribbean Geological Conference, 268-281.

Schellekens, J.H., 1998. Geochemical evolution and tectonic history of Puerto Rico. In: Lidiak, E.G., Larue, D.K. (eds.). Tectonics and Geochemistry of the Northeastern Caribbean. Boulder, Colorado, Geological Society of America Special Paper, 322, 35-66.

Seiders, V.M., 1971. Cretaceous and lower Tertiary stratigraphy of the Gurabo and El Yunque quadrangles, Puerto Rico. United States Geolological Survey Bulletin, 1294-F, 58 pp.

Shaw, D.M., 1970. Trace element fractionation during anatexis. Cosmochimica et Geochimica Acta, 34, 237-43.

Sun, S.S., McDonough, W.F., 1989. Chemical and Isotopic systematics of oceanic basalts. In: Saunders, A., Norry, M. (eds.) Magmatism in Ocean Basins. Geological Society of London, Special Publication, 42, 313-45.

Tatsumi, Y., Nohda, S., Ishiszaka, K., 1988. Secular variation in magma source compositions beneath the northeast Japan arc. Chemical Geology, 68, 309-316. 
Thirlwall, M.F., Graham, A.M., 1984. Evolution of high-Ca, high-Sr C-series basalts from Grenada, Lesser Antilles: the effects of intra-crustal contamination. Journal of the Geological Society of London, 141, 427-45.

Van Gestel, J., Mann, P., Dolan, J., Grindlay, N. R., 1998. Structure and tectonics of the upper Cenozoic Puerto Rico-Virgin Islands carbonate platform as determined from seismic reflection studies. Journal of Geophysical Research, Solid Earth, 103, B12, 30,505-30,530.

Van Gestel, J., Mann, P., Grindlay, N.R., Dolan, J., 1999. Three-phase tectonic evolution of the northern margin of
Puerto Rico, as inferred from an integration of seismic, well, and outcrop data. Marine Geology, 161, 259-288.

Vila, J.-M., Andreiett, P., Bellon, H., Mascle, A, 1986. Tectonique de collage le long d'un accident décrochand, ante oligocéne, est-ouest, dan les Iles Vierges septentrionales (Antilles). Paris, Comtes Rendus Académie des Sciences, Tome 302, serie II, no. 3, 141-144.

Woodhead, J., Eggins, S., Johnson, R., 1998. Magma genesis in the New Britain island arc: Further insights into melting and mass transfer processes. Journal of Petrology, 39, 1641-1668.

Manuscript received September 2004;

revision accepted September 2005. 


\section{APPENDIX}

\section{Analytical results}

TABLE 1 I Northeast Antilles volcanic unit names and codes, ages (from Fig. 5), and estimated sediment proportions (from Fig. 14).

Unit code and name

\section{Virgin Islands}

1. WI Water Island Formation Low HFSE Basalt

2. WI Water Island Formation Low HFSE Plagiorhyolite

3. WI, Water Island Formation High HFSE Plagiorhyolite

4. HL2, Tortola Formation, Carrott Bay Member 1

6. SM, Tortola Formation, Sage Mt. Member

5. SB, Tortola Formation, Shark Bay Member

7. HL1, Tortola Formation, Carrott Bay Member 2

8. LHA Lousienhoj Formation, Member A

9. LH B and C, Louisenhoj B and C

10 TUA, Tutu Formation, Member A

11.TUB, Tutu Formation B

12.TUC, Tutu Formation C

$\mathrm{HH}$, Water Island Formation High-HFSE MORB-like basalt

LH, Water Island Formation Low-HFSE MORB-like basalt

\section{Central Puerto Rico}

13. CPRI J, Formation J

14. CPRI $B$ and $C$, Formations $B$ and $C$

15. CPRI $A$ and $L A$, Formation $A$ and lower Formation $A$

16. CPRIII Av 1and 2, Avispa Formation

17. CPRII TOR, Torrecilla Formation

18. CPRII PTH, Pitahaya Formation

19. CPRIII Hyb Perchas-Lapa Hybrids

20A. CPRIII PE, Perchas Formation

20B CPRIII RG, Rio Grande Pluton

21A. CPRIII LT, Las Tetas Member

21B.CPRIII LL, Lapa Lava Member

Northeastern Puerto Rico

22A. NEPRII FG, Fajardo Formation

22B NEPRII CG, Cerro Gordo Formation

23. NEPRIII INF, Infierno

24. NEPRIII SO, Santa Olaya Formation

25. NEPRI DG, Dagauo Formation

26. NEPRI FG, Figuera Formation

LOM, Lomas Formation

SO2, Santa Olaya Formation Member 2

\section{Eastern Puerto Rico}

27. EPR IV, Pozas, Mamey, Tortugas, M. Gonzales Formations

28. EPR V GUR, Guracanal Formation

29. EPRIV RdP, Rio de la Plata Formation

30. EPR V YUN, Formation (not shown)

31. EPR V JOB, Formation (not shown)
Age, Ma

$\%$ Sediment

112-105

$112-110$

$55-50 ?$

$50-45 ?$

$50-45 ?$

$55-50 ?$

105-90?

105-90?

85-75

$85-75$

$85-75$

112-105

$112-1050$

0

Crustal melt

Crustal melt

0.6

0.8

0.4

0.7

0.7

0.7 .

2.1

1.2

1.2

0.4

1.5

$\sim 105$

$\sim 110$

0.4

$115-110$

0.7

1.1

90-85

$\sim 100$

$\sim 100$

95-90

$95-90$

95-90

$90-85$

95-90

3.1

3.8

4.5

7.0

8.0

8.0

2.8

4.0

\section{5}

105

0.8

90-85

0.8

100-85

112

110-105

90-85

100-85

1.2

0.7

0.7

1.0

1.0-4.0

4.0

85-70

2.5

60

2.6

85-80

60-55

55-45
4.0

4.0-1.0

0.5 
TABLE 2 Major and trace element analyses from Atlantic Cretaceous pelagic sediment (AKPS) and representative island arc volcanic rocks from the Virgin Islands and Puerto Rico.

\begin{tabular}{|c|c|c|c|c|c|c|c|c|c|c|}
\hline & 1 & 2 & 3 & & 4 & 5 & 6 & 7 & 8 & 9 \\
\hline Suite & AKPS & AKPS & AKPS & & AKPS & AKPS & AKPS & AKPS & AKPS & AKPS \\
\hline Sample & $105 / 15 / 6$ & $105 / 18 / 6$ & $105 / 37 / 5$ & & $105 / 37 / 6$ & $105 / 22 / 5$ & $417 / 12 / 3$ & $417 \mathrm{D} / 18 / 2$ & 417D/19/1 & $417 d / 21 / 3$ \\
\hline $\mathrm{SiO}_{2}$ & 65.94 & 23.42 & 57.84 & & 54.52 & 34.25 & 69.68 & 67.84 & 82.02 & 45.07 \\
\hline $\mathrm{Al}_{2} \mathrm{O}_{3}$ & 17.57 & 5.12 & 11.79 & & 13.04 & 6.77 & 11.43 & 14.16 & 7.76 & 8.41 \\
\hline $\mathrm{Fe}_{2} \mathrm{O}_{3} \mathrm{t}$ & 6.41 & 2.72 & 5.68 & & 6.82 & 13.38 & 4.44 & 5.87 & 3.96 & 24.03 \\
\hline $\mathrm{MgO}$ & 2.77 & 1.33 & 2.34 & & 2.88 & 2.01 & 4.23 & 5.84 & 1.94 & 2.69 \\
\hline $\mathrm{MnO}$ & 0.02 & 0.08 & 0.23 & & 0.71 & 0.10 & 0.04 & 0.06 & 0.02 & 0.11 \\
\hline $\mathrm{CaO}$ & 0.58 & 64.47 & 17.71 & & 16.71 & 39.14 & 3.58 & 0.60 & 0.68 & 13.81 \\
\hline $\mathrm{Na}_{2} \mathrm{O}$ & 2.26 & 1.18 & 1.14 & & 1.15 & 1.24 & 1.39 & 1.73 & 0.89 & 1.30 \\
\hline $\mathrm{K}_{2} \mathrm{O}$ & 3.61 & 1.41 & 2.67 & & 3.44 & 2.37 & 2.72 & 3.19 & 2.10 & 3.34 \\
\hline $\mathrm{TiO}_{2}$ & 0.77 & 0.22 & 0.52 & & 0.65 & 0.32 & 0.51 & 0.61 & 0.34 & 0.42 \\
\hline $\mathrm{P}_{2} \mathrm{O}_{5}$ & 0.06 & 0.05 & 0.09 & & 0.06 & 0.36 & 1.98 & 0.11 & 0.29 & 0.81 \\
\hline $\mathrm{Cr}_{2} \mathrm{O}_{3}$ & 0.007 & 0.002 & 0.00 & & 0.007 & 0.004 & 0.017 & 0.002 & 0.004 & 0.006 \\
\hline C & 1.03 & 0.21 & 3.58 & & 3.16 & 2.27 & 5.53 & 0.21 & 0.14 & 4.33 \\
\hline LOI & 16.00 & 36.80 & 18.06 & & 17.50 & 34.65 & 19.60 & 15.50 & 8.36 & 32.55 \\
\hline $\mathrm{Ba}$ & 631 & 1 & 216 & & 298 & 787 & 759 & 759 & 2142 & 1786 \\
\hline $\mathrm{Ce}$ & 83.42 & 45.77 & 76.97 & & 85.78 & 86.01 & 73.78 & 55.31 & 91.37 & 125.79 \\
\hline Co & 35 & 21 & 33 & & 58 & 19.5 & 21 & 19 & 13 & 18 \\
\hline Cs & 8.55 & 3.04 & 5.41 & & 7.36 & 4.16 & 6.40 & 7.1 & 5.17 & 5.28 \\
\hline Dy & 4.86 & 3.95 & 4.77 & & 4.96 & 7.88 & 8.21 & 3.36 & 9.64 & 11.81 \\
\hline $\mathrm{Er}$ & 2.72 & 2.06 & 2.51 & & 3.10 & 4.16 & 5.26 & 2.14 & 4.77 & 6.25 \\
\hline $\mathrm{Eu}$ & 1.25 & 1.09 & 1.46 & & 1.40 & 2.25 & 2.06 & 0.94 & 2.70 & 3.40 \\
\hline $\mathrm{Gd}$ & 5.43 & 5.01 & 5.39 & & 6.30 & 9.74 & 9.50 & 3.88 & 12.04 & 14.46 \\
\hline $\mathrm{Hf}$ & 3.83 & 1.44 & 2.69 & & 4.28 & 1.84 & 2.37 & 3.09 & 1.53 & 2.23 \\
\hline Ho & 0.98 & 0.80 & 0.89 & & 1.08 & 1.55 & 1.92 & 0.68 & 1.88 & 2.29 \\
\hline La & 40.93 & 28.81 & 39.47 & & 46.14 & 47.57 & 53.45 & 28.43 & 47.17 & 66.33 \\
\hline Lu & 0.49 & 0.29 & 0.34 & & 0.45 & 0.56 & 0.77 & 0.37 & 0.59 & 0.83 \\
\hline $\mathrm{Nb}$ & 15.3 & 5.6 & 10.2 & & 13.0 & 6.7 & 9.0 & 9.0 & 11.2 & 7.7 \\
\hline $\mathrm{Nd}$ & 33.34 & 23.85 & 32.71 & & 39.02 & 46.67 & 47.68 & 24.25 & 59.70 & 69.49 \\
\hline $\mathrm{Ni}$ & 185 & 75 & 116 & & 139 & 207 & 153 & 90 & 67 & 338.0 \\
\hline $\mathrm{Pb}$ & 21 & 12 & 20 & & 22 & 18 & 16 & 15 & 17 & 24 \\
\hline $\operatorname{Pr}$ & 8.20 & 5.78 & 8.19 & & 9.22 & 11.11 & 10.65 & 6.28 & 13.04 & 16.43 \\
\hline $\mathrm{Rb}$ & 150 & 61 & 112 & & 133 & 94 & 114 & 149 & 92 & 127 \\
\hline $\mathrm{Sm}$ & 7.46 & 5.76 & 6.15 & & 7.85 & 10.80 & 9.66 & 5.02 & 12.20 & 15.83 \\
\hline $\mathrm{Sr}$ & 222 & 790 & 174 & & 180 & 514 & 175 & 81 & 105 & 237 \\
\hline $\mathrm{Ta}$ & 0.96 & 0.32 & 0.74 & & 0.86 & 0.43 & 0.63 & 0.84 & 0.33 & 0.53 \\
\hline $\mathrm{Tb}$ & 0.83 & 0.67 & 0.80 & & 0.86 & 1.42 & 1.38 & 0.63 & 1.81 & 2.16 \\
\hline Th & 13.60 & 5.76 & 7.38 & 9.45 & 8.03 & 8.03 & & 8.36 & 8.14 & 10.29 \\
\hline $\mathrm{Tm}$ & 0.39 & 0.29 & 0.38 & 0.47 & 0.58 & 0.79 & & 0.37 & 0.67 & 0.86 \\
\hline$U$ & 3.13 & 3.52 & 0.86 & 1.10 & 8.00 & 12.05 & & 2.63 & 0.66 & 12.49 \\
\hline V & 150 & 86 & 80 & 109 & 465 & 355 & & 110 & 89 & 844 \\
\hline$Y$ & 29 & 27 & 30 & 31 & 51 & 60 & & 22 & 55 & 74 \\
\hline $\mathrm{Yb}$ & 2.97 & 1.65 & 2.24 & 2.98 & 3.36 & 5.16 & & 2.32 & 4.27 & 5.07 \\
\hline $\mathrm{Zr}$ & 122 & 45 & 92 & 130 & 66 & 93 & & 115 & 60 & 86 \\
\hline
\end{tabular}




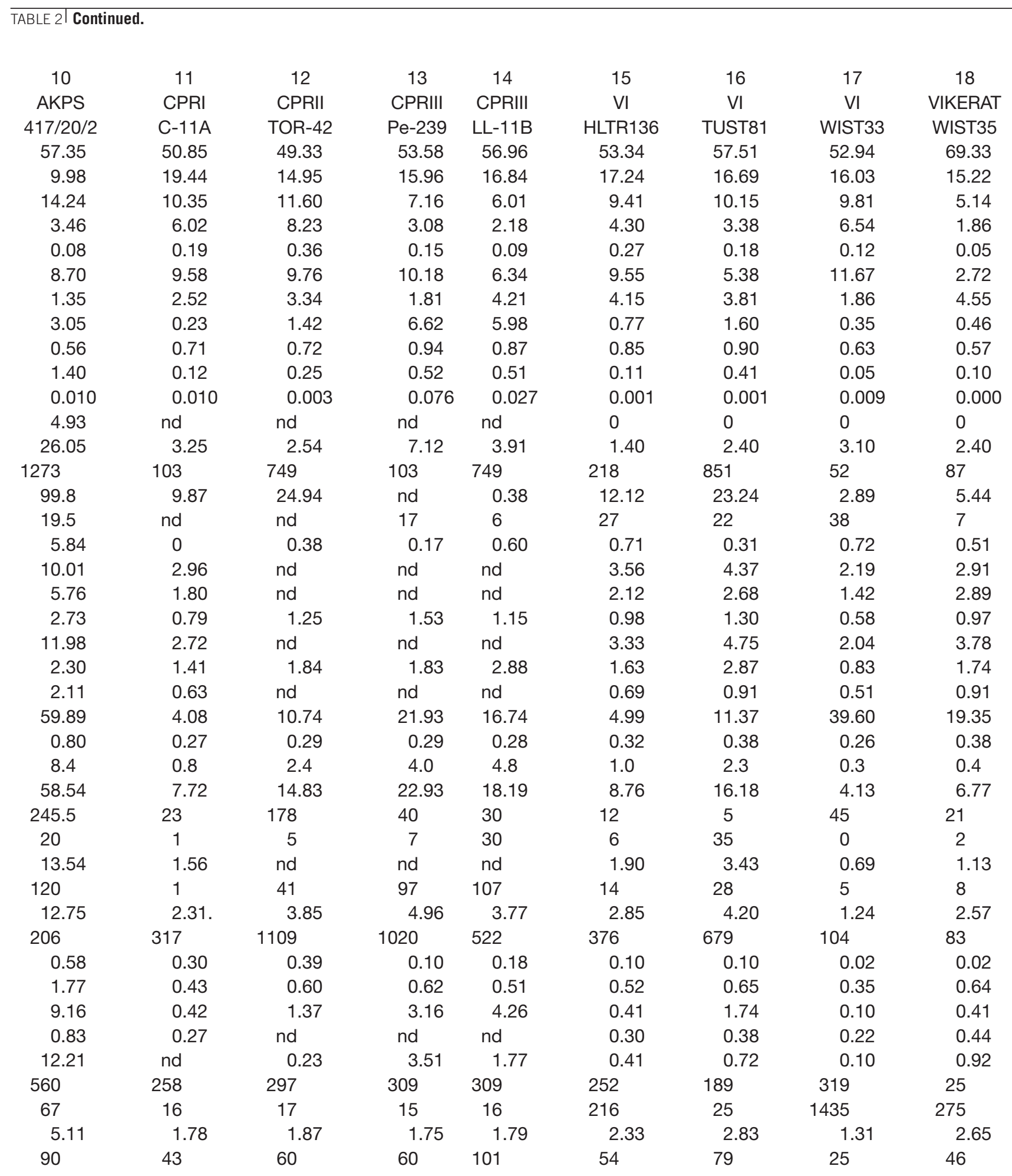


TABLE 3 I Nd, Sr, and Pb isotope data for Atlantic Cretaceous pelagic sediment (AKPS); major and trace element data are presented in Table 2.

\begin{tabular}{|c|c|c|c|c|c|c|c|c|}
\hline Sample & ${ }^{144} \mathrm{Nd} /{ }^{143} \mathrm{Nd}$ & $\varepsilon_{\mathrm{Nd}}$ & ${ }^{87} \mathrm{Sr} /{ }^{86} \mathrm{Sr}$ & $i^{87} \mathrm{Sr} /{ }^{86} \mathrm{Sr}$ & ${ }^{206} \mathrm{~Pb} /{ }^{204}$ & ${ }^{7} \mathrm{~Pb} /{ }^{204} \mathrm{~Pb}$ & ${ }^{208} \mathrm{~Pb} /{ }^{204} \mathrm{~Pb}$ & Age(Ma \\
\hline \multicolumn{9}{|c|}{ Hole 417} \\
\hline $12 / 3$ & 0.512083 & -9.929 & 0.71489 & 0.71243 & & & & 95 \\
\hline $18 / 2$ & 0.511963 & -12.256 & 0.72837 & 0.72103 & 18.99 & 15.68 & 39.06 & 100 \\
\hline $19 / 1$ & 0.512187 & - 7.821 & 0.71488 & 0.71124 & 18.90 & 15.72 & 39.08 & 105 \\
\hline $21 / 3$ & 0.512202 & - 7.681 & 0.71302 & 0.71067 & 19.35 & 15.71 & 38.63 & 110 \\
\hline \multicolumn{9}{|c|}{ Hole 105} \\
\hline $15 / 6$ & 0.512726 & -9.266 & 0.71436 & 0.71140 & 18.88 & 15.69 & 38.93 & 110 \\
\hline $18 / 6$ & 0.512196 & - 7.882 & 0.70821 & 0.70785 & 18.93 & 15.68 & 38.86 & 115 \\
\hline $37 / 5$ & 0.512151 & - 8.020 & 0.71425 & 0.71065 & 18.75 & 15.70 & 38.97 & 140 \\
\hline $37 / 6$ & 0.512135 & -8.428 & 0.71661 & 0.71234 & 18.73 & 15.69 & 38.92 & 145 \\
\hline
\end{tabular}

TABLE 4 Average abundances (ppm, $n=10$ ) of stable incompatible elements in Atlantic Cretaceous pelagic sediment (AKPS), from north of the Puerto Rico Trench at DSPD sites 105 and 417D.

$\begin{array}{lrlcll}\mathrm{Th} & 8.43 & \mathrm{Nd} & 48.97 & \mathrm{~Tb} & 1.14 \\ \mathrm{Nb} & 9.66 & \mathrm{Zr} & 93 & \mathrm{Dy} & 6.53 \\ \mathrm{Ta} & 0.61 & \mathrm{Hf} & 2.69 & \mathrm{Ho} & 1.34 \\ \mathrm{La} & 45.01 & \mathrm{Eu} & 7.02 & \mathrm{Er} & 3.70 \\ \mathrm{Ce} & 64.99 & \mathrm{Ti} & 3000 & \mathrm{Tm} & 0.54 \\ \mathrm{Pr} & 9.07 & \mathrm{Gd} & 7.81 & \mathrm{Yb} & 3.11\end{array}$

